\title{
ORGANIZING VISION AND LOCAL IS PRACTICES: \\ A FRANCE-U.S. COMPARISON
}

\author{
Sabine Carton \\ CERAG UMR 5820, IAE Grenoble, and Préactis \\ Pierre Mendès France University, Grenoble, France \\ $\underline{\text { Sabine.carton@iae-grenoble.fr }}$ \\ François-Xavier de Vaujany \\ ISEAG - Préactis \\ Jean Monnet University, Saint-Etienne, France \\ devaujaf@univ-st-etienne.fr
}

Cécile Romeyer

ISEAG - Préactis

Jean Monnet University, Saint-Etienne, France

Cecile.romeyer@univ-st-etienne.fr

\section{$\rho$ ABSTRACT}

In their Organizing Vision model, Swanson and Ramiller called for more research on the relationship between inter-organizational "authorized" (legitimated) discourse on IT and organizational practices. In this paper, the research question is focused on national differences in the way cross-organizational discourses interact with local practices. The methodology used includes the identification of so-called "authorized" ideas through an analysis of both French and US publications (using thematic and lexicometric analysis), as well as IT forums, from 1999 to 2003. This analysis is then merged with an overview of French and American case studies. The results demonstrate strong differences in the OV production systems, as well as in organizational behaviour's reaction to cross-organizational discourse.

Keywords: France-US Comparison, IT, IT press, organizing vision, institutionalism 


\section{Introduction}

In the French think-tank DIGITIP's view, as well as for a number of experts, France demonstrated a significant structural lag in terms of technological investment compared to the United States, particularly throughout the key period of the 1990s. Indeed, the proportion of government investment in IT was, at the beginning of the 1980s, "(...) two and a half times higher in the US than in France" [Melka and Nayman, 2003; p.2]. In the following period, however, it should be noted that IT investment increased at a relatively similar pace, except for the first half of the $90 \mathrm{~s}$, when the lag in France was reinforced by slow national economic growth (OECD 2002; Melka and Nayman, 2003]. At the end of the period, a significant gap between French and American IT expenses per capita ( $€ 2,650$ for USA and $€ 1,430$ for France in 2001) could be noted [see Fomin et al. 2003] underlined. This gap decreased slightly in 2002 ( $€ 2,430$ for the US and $€ 1,491$ for France) [Federal Statistics Office, 2003].

In fact, some significant main differences between France and the US can be underscored. IT investment from 1995 to 2000 is clearly greater in the US than in France. However, the most interesting result is the following: IT contribution to productivity is demonstrated in the figures to be twice as high in the US as it is in France. Melkan and Neyman further underscore this point when they observe that "Today, the French 'gap' (in comparison to the USA) has to be overcome more by the way people adapt to technological changes than by investing in new IT" (2003, p.4).

From 2001 to 2003, this gap has been confirmed. Even if in terms of volume, France and the rest of the world still lag behind, the gap is filled in terms of productivity. IT investment in components (Web technology, Intranets, Extra-nets, ERP) in France and in the USA is similar but does not evolve at the same pace. In 2000,69\% of American companies implemented an Extra-net and $52 \%$ of them had set up a web site [Association of National Advertisers, October 2001]. For the same period, the French reality is far from the same: to obtain the same sort of figures for the number of inter-net 
sites per company, the inquiry must be limited to only the 1,000 largest French companies (!) [Benchmark group, 2001].

Beyond such macro-social or macro-economic concerns, we are seeking here to understand differences in the IT representations and practices between France and the US in the 90's by asking the following questions:

Q1: What differences exist in the representations of the IT tools that flooded French and American firms (web, e-business, Intranets, extranets, KM) from 1999 to 2003 when "the new economy" rose and then declined?

Q2: How, on a more micro-social level, have organizations reproduced, transformed or instrumentalized this social environment?"

In order to provide answers to these questions, we have implemented a recent model in the IS field: the Organizing Vision or O.V. [Swanson and Ramiller, 1997, 2003, 2004]. This model enables us to understand the social framework, as well as the specific vision of innovative IT in the US compared to France, and to highlight the OV's specific careers (e.g. its lifespan) in both of the geographic areas studied.

Swanson and Ramiller's model will be presented first, as well as the choice of the application model. Second, a France-USA comparison will be developed based on a content-based and lexical-based analysis of French and American weekly publications. A case study analysis will be then carried out to better understand the differences between the lifespan (or career) of French and American OVs. To conclude, we will focus on the limitations of our work and its relevance, particularly to transnational firms whose IS cross French and American borders. 


\section{REVIEW OF THE ORGANIZING VISION MODEL AND PRESENTATION OF APPLICATION MODES}

[Swanson and Ramiller's, 1997, 2003, 2004] Organizing Vision model is first revisited. The application strategies for the theoretical framework will be then reviewed. The method chosen for our research purposes is ultimately developed.

\section{LINKING INSTITUTIONAL AND MICRO-SOCIAL EVOLUTION: THE ORGANIZING VISION MODEL}

In IS literature, two main approaches are deployed to study company practices for adopting new technologies. The first one studies adoption mechanisms within a company, and focuses on obstacles (inhibitors) as well as facilitators between individuals. This approach enables us to explain power struggles, psychological obstacles and managerial leveraging within an organization. The second approach takes on a broader perspective and analyses this adoption process at an institutional level, enabling us to reflect on the specific role of a technology, its use, and its impact on a specific sector, a country, or countries. This institutional approach highlights, from a political, economic or sociological perspective, how adoption practices take shape [Di Maggio and Powell, 1991].

Swanson and Ramiller's perspective attempts to combine two kinds of approaches with one unifying concept: the Organizing Vision. For these authors, the OV concept refers to "a focal community idea for the application of information technology in organizations" (1997, p 460). The OV's content is related to: the proper implementation of the technology, to the conditions necessary to benefiting from its added value, and the organizational changes that this brings about [Swanson and Ramiller 1997].

This concept underlines that the processes behind choosing to adopt a technology, as well as its implementation in an organization, must not be dissociated from outside discourses relayed by the general environment surrounding this organization (the media, 
IS consultants, competitors).

Thus, in their model, three different levels of discourse that create and enrich OVs have been identified:

- The first one called as the "cultural and linguistic resources" levels represents the macro level. It is illustrated through the discourse of "IS practitioner subculture" and discourses from "business problematics",

- The second level is the "Social structure" level: this "community" level gets enrich by local discourses. It could be considered as an intermediate level,

- Finally the "Practical activities and objects" level. This micro level is represented by local stories of "adoption of a technology", local "technological adaptation", local discourses of "commerce".

It in fact offers a kind of cross-organizational grid on adoption mechanisms for a new technology, on the level of every participant in the organization targeted.

The authors suggest that the OV tends to become increasingly rich through media discourse, past adoption experience, or forums for exchanges (newspapers, conferences, clubs). Thus, the OV's content can evolve over time. However, it could also be that in the long run, it suffers from "a lack of coherence, reflecting the ambiguities that surround the innovation" ( $p$ 463).

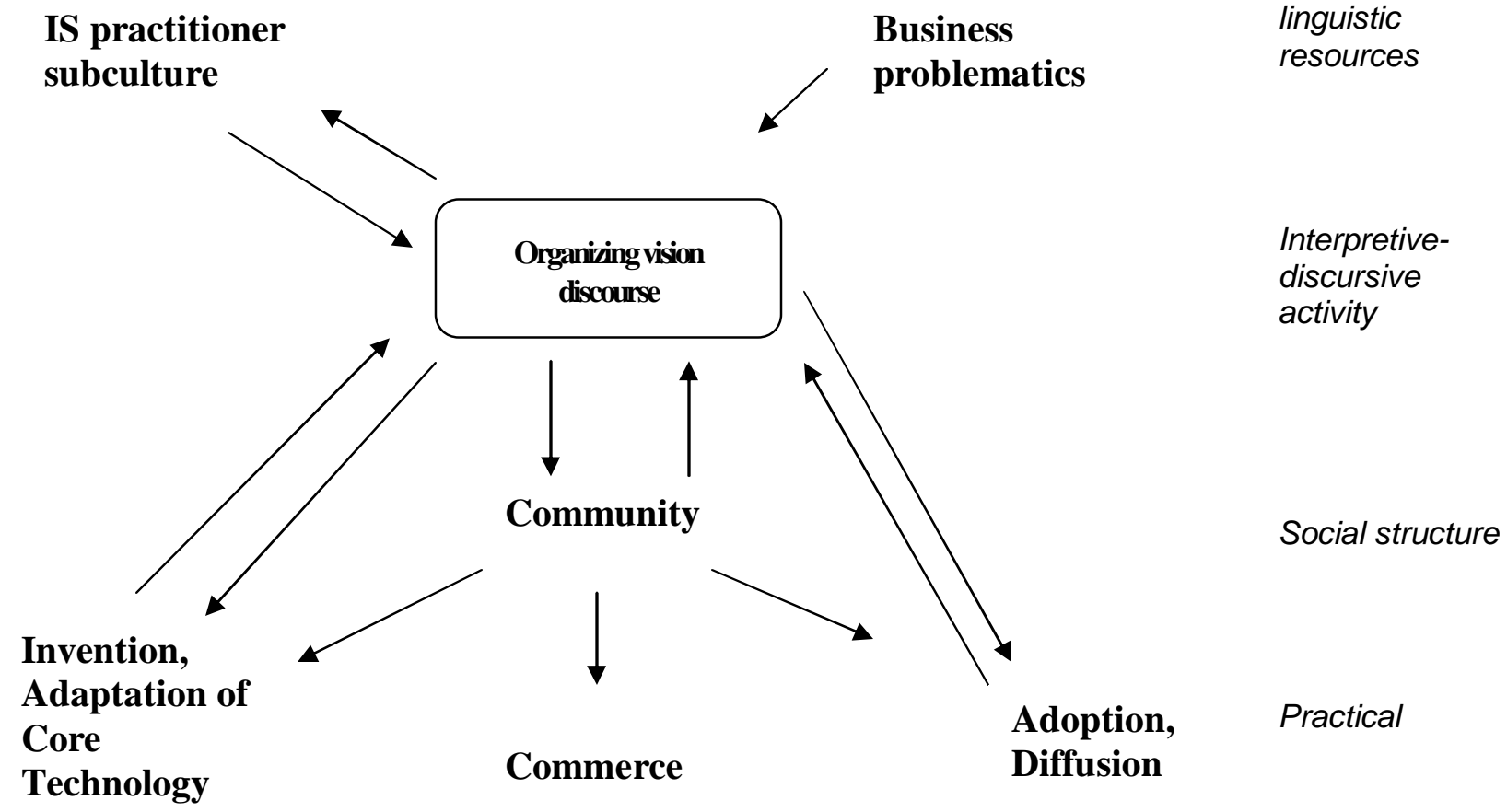


activities and

objects

Figure 1: Institutional Production of Organizing Visions [Swanson and Ramiller, 1997]

Managers can then interpret, reproduce, transform or circumvent "authorized ideas" in their business activities. It will then depend on the organization's level of reflexivity ("mindfulness"), or sensitivity to its external environment [Ramiller and Swanson, 2004].

The question of whether an OV is transmitted from one country to another, and whether or not it is enriched through multinational firms' practices is not mentioned specifically by Swanson and Ramiller. The OV concept can thus be productive to our study for understanding multinationals' IT adoption practices.

In their 1997 article (as in their more recent papers), Swanson and Ramiller remain relatively evasive on their model's application modes. They suggest the existence of some discursive structures and key words ("buzzwords") which may reveal strong ideas behind the representation of the OV. The authors also emphasize that studies on OV "should differ substantially from conventional innovation studies, in particular, by focusing on the organizing vision's evolving text and institutional presence, rather than on the adoption practices of individual organizations" ( $p$ 471).

\section{THREE STRATEGIES FOR APPLICATION}

To date, three main application strategies for OVs exist in scholarly writings [Carton, de Vaujany and Romeyer, 2003]: a targeted ascending strategy, a media strategy, and a general descending strategy.

When applying what we call the 'targeted ascending strategy', the analysis begins at a micro level of social dynamics (revealed by case studies) based on a general notion of technology (web, intranet, extranet, ERP, etc.) to then 'ascend' upwards towards institutional dynamics. [Firth 2001], [Wang and Swanson 2003], as well as [Swanson and Ramiller 2003] have implemented this kind of approach. 
A 'media strategy' is based on studying the various forums where the OV tends to be expressed (newspapers, conferences, professional clubs). One can thus examine general discourse on a directly societal or cross-organizational level, such as in Wang's (2001) research and application.

Lastly, the 'general descending strategy' is a combination of the two preceding strategies. Using societal or cross-organizational discourses as a starting point (with a wide variety of technological concepts), it is then inquired into their impact on social dynamics at the micro level. For the sake of comparison will thus be superimposed local case studies onto institutional discourses.

This latter strategy is advantageous for three main reasons. First, it offers a broader access to cross-organizational discourse (with the possibility of more clearly connecting OVs to their potential lifespan). Second, it offers a greater degree of reliability for assessing the degree of institutionalisation (beyond local effects), and third, it provides the possibility of systematically treating cross-organizational discourses (through lexical and content-based analyses of publications).

From our perspective, it is the third strategy alone that is capable of integrating all of the OV model's components, including cross-organizational representations (initial conception and then broadcasting among specific forums) as well as micro-social practices which will reproduce, reinforce, instrumentalize, or transform the OV. It implies both an analysis at a macro-level as well as at a micro-level. As [Whittington 2006] points: "Appreciation of wider contexts can help make intelligible many of the complex details revealed by intimate investigations. Reciprocally, close engagement can uncover the real ambiguity and fluidity of the broad strategy trends found in sectoral or societal analyses". A complete analysis involves thus looping the two levels more closely together. That is why our analysis will be focused both on intra and inter-organizational levels and their interplay.

\section{RESEARCH STRATEGY CHOSEN FOR FRANCE-US INFORMATION SYSTEMS COMPARISON}

From a technical point of view, the general strategy for our descending-type of 
research has been applied as follows:

- On the level of cross-organizational discourse analysis, it was looked at forums and actors presenting elements that echo with Organizing Visions. A content analysis from articles published from 1999 to 2003 was carried out by means of thematic and lexico-metric analyses applied to titles and the articles' bodies. Four institutional media have been analyzed to carry out the analysis. They have been chosen because of their large audience to their national IS community (For French IS community: "01 Informatiques" and Le Monde Informatique" and for US IS community: "Computerworld" and "Informationweek"). "In addition, throughout this period we equally analysed discourse from professional organizations (such as CIGREF, AITP) as well as from IT conferences (such as Interop). In order to identify media of interest, we studied references appearing on Internet search engines and thematic catalogues of specialized sites (such as the "Journaldunet" database of professional associations linked to Internet and computers: http://www.journaldunet.com/dossiers/associations), as well as expert opinions found on the Web. Our goal was to analyse a whole set of forums that were being deployed for OV production. The various data-processing types we performed on these forums are presented in Appendix A.1.

- On the level of local practices, an analysis was conducted based on published case studies (particularly in the environmental, healthcare, and banking sectors). We collected these case studies based predominantly on IT development and implementation from EBSCO, PROQUEST, 'Google scholar' and different academic sites.

A global perspective of the methodological choice is indicated here below. The table highlights how the methodology is articulated with the theoretical model from Swanson and Ramiller, as well as the choice of the methodological tools used.

Table 1. : Research Methodology roll out

\begin{tabular}{|l|l|lr|}
\hline & Media analysis (cf. part III) & \multicolumn{2}{|c|}{ Longitudinal study (cf. part IV) } \\
\hline Theoretical model & $\begin{array}{l}\text { Community, commerce, global } \\
\text { adoption, discourse of technology }\end{array}$ & $\begin{array}{lr}\text { IS practitioner subculture, } \\
\text { business problematics, local }\end{array}$ \\
\hline
\end{tabular}




\begin{tabular}{|c|c|c|}
\hline & global adaptation & $\begin{array}{l}\text { adoption, discourse of technology } \\
\text { local adaptation and } \\
\text { implementation }\end{array}$ \\
\hline Level of analysis & Macro level & Micro level \\
\hline Methods used & $\begin{array}{l}\text { Analysis of four institutional media } \\
\text { (two French and two US) from } \\
1999 \text { to 2003. Analysis focused } \\
\text { on titles of articles. }\end{array}$ & $\begin{array}{l}\text { Analysis of case studies based on } \\
\text { common criteria. }\end{array}$ \\
\hline Tools used & $\begin{array}{l}\text { Content analysis (first, } \\
\text { identification of themes and then } \\
\text { classification of articles based on } \\
\text { the identified themes) } \\
\text { Pivot analysis (identification of } \\
\text { words set closed to the chosen } \\
\text { keywords), } \\
\text { Lexical analysis (number of } \\
\text { occurrences of chosen keywords, } \\
\text { most-frequently used keywords) }\end{array}$ & $\begin{array}{l}\text { Selection of case studies from } \\
\text { EBSCO, PROQUEST, 'Google } \\
\text { scholar' and different academic } \\
\text { sites. }\end{array}$ \\
\hline Keywords used & $\begin{array}{l}\text { ERP, Internet, Intranet, web, } \\
\text { wireless }\end{array}$ & $\begin{array}{l}\text { Intranet; ERP, e-business, } \\
\text { specific activity sectors, such as } \\
\text { the Environmental, banking or } \\
\text { Healthcare industries. }\end{array}$ \\
\hline
\end{tabular}

\section{A FRENCH-AMERICAN COMPARISON OF ORGANIZING VISIONS}

First, a thematic and lexico-metric analysis is presented. It is based on French and American institutional media. This work is then complemented with an analysis of professional organizations and conferences. French and American OVs and their evolutions are then identified, exposed and elucidated over the period 1999-2003.

\section{RESPECTIVE EVOLUTIONS OF FRENCH AND AMERICAN MEDIA DISCOURSES}

Several textual analyses are applied to the four different publications. These techniques 
are applied as follows (see table 2):

Table 2. Methodological tools used for each publication

\begin{tabular}{|l|c|c|c|c|}
\hline & \multicolumn{2}{|c|}{ United States } & \multicolumn{2}{c|}{ France } \\
\hline $\begin{array}{l}\text { Weekly } \\
\text { publications } \\
\text { chosen }\end{array}$ & Computerworld & Informationweek & 01 informatique & $\begin{array}{l}\text { Le Monde } \\
\text { Informatique }\end{array}$ \\
\hline $\begin{array}{l}\text { Lexicometric } \\
\text { Analysis }\end{array}$ & $X$ & $X$ & $X$ & $X$ \\
\hline Pivot analysis & $X$ & $X$ & $X$ & $X$ \\
\hline $\begin{array}{l}\text { Thematic } \\
\text { content } \\
\text { analysis }\end{array}$ & & $X$ & $X$ & \\
\hline
\end{tabular}

\section{Organizing Vision from the perspective of Computerworld}

An analysis of the most frequently-used words appearing in Computerword magazine was conducted from 1999 to 2003. It enabled us to identify several salient aspects:

A significant increase in the field of Security during all four years, with a slowdown beginning for the first two quarters of 2003 (the number of times the word 'security' occurs increased for four years to then begin to decrease). Pivot analyses (i.e. occurrences right before or after a given word) indicate a high, repetitive use of action verbs in 2002 ("improve ", " test", " alter ", "centralize ") while the discourse tended to be different relating to security issues ("failure ", "default", "problems ", "hole", "flaw", "war ").

The years 1999 and 2000 reveal a period where magazine discourse was highly repetitive on strong key words illustrating technological concepts (number of occurrences highest for the period relating to the following keywords: "Internet", 
"Web ", “ERP ”, “business ”, “wireless ", “commerce ", " net ", “ CRM ").

Certain management-oriented discourses on key buzzwords became trendier depending on the given year: for example the word "Integration" was highest in 2000, or the word "Collaboration" peaked in 2001.

There was a significant presence of key IT business players in the magazine titles throughout the period studied, with some IT companies widely quoted (Microsoft, IBM).

For the sake of comparison, five IT buzzwords, or fashion (Wang, 2006) have been identified and analyzed based on the four publications. The following graph shows the five keywords selected.

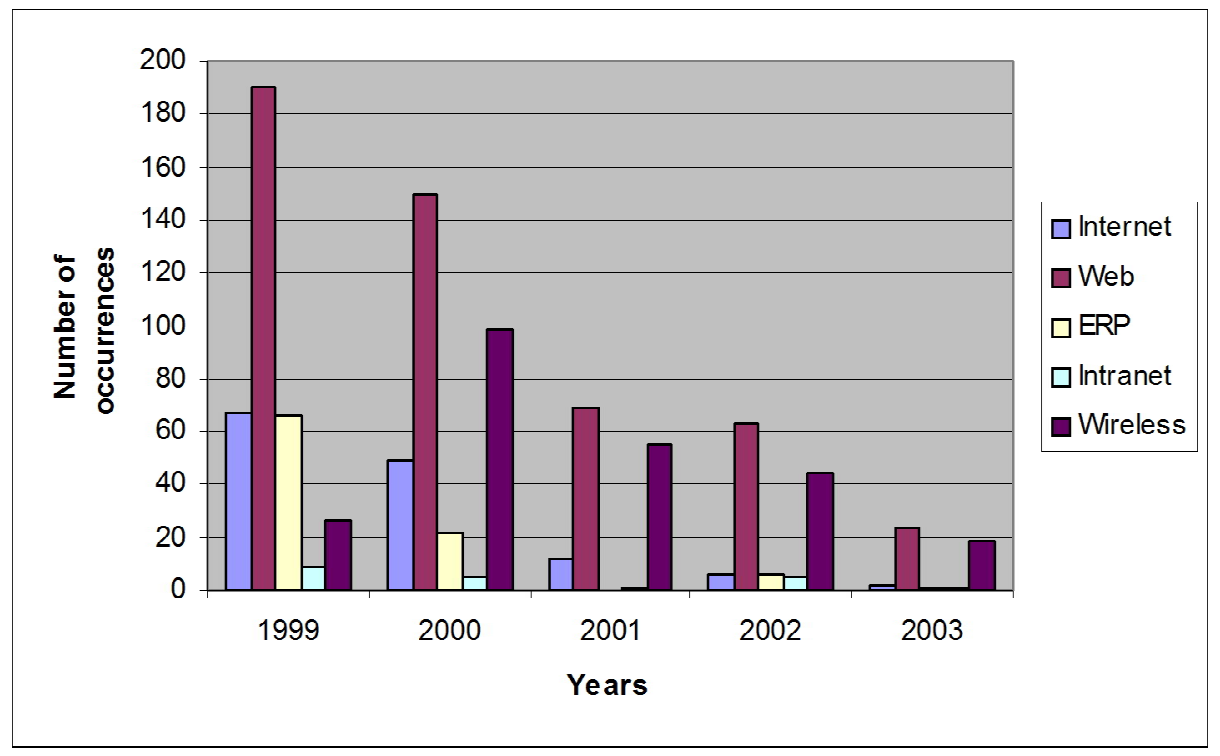

Figure 2: Tracking Five Technological Concepts in Computerworld

A pivot analysis on the keywords targeted enabled us to specify content from the discourse associated with these words. Throughout the period studied, the frequency of the word 'Internet' decreased. In 1999, when the frequency was high, the discourse was heterogeneous, mixing security issues, the competitive positioning of the various players on the market, the potential applications of the Internet, as well as inquiry into the issues of taxation and the Internet. Thus in 2000, the discourse focused on legal aspects (" laws apply equally to internet sales ", " advertising, ABA Panel calls for global internet 
laws"), then in 2001 on potential applications, including more theoretical aspects ("reinventing the internet ", "thinking draws life from internet") to end, in 2003, with a more technical orientation.

In 1999, the discourse on the "web" Organizing Vision is wide-ranging, dealing with both web commercial interests and interactions with other technological concepts such as ERP, EDI, or groupware. In 2000, this discourse focused mainly on the interaction between "web" and "wireless" ("wireless meets web", "wireless web access will be vital') and on the security dimension ("software to help web attacks", "guardians of your web security", "how companies can enhance web security"). Since 2001, the frequency of the term "webservices" has exploded, indicating a seemingly limitless potential.

Over the period studied, the term "ERP" was highly linked to editors promoting these technological concepts, revealing competition between offers, the respective positions of each ("Peoplesoft speeds ERP installations and upgrades", "Oracle to boost ERP add support", “who's leading the ERP race?"). After 2000, this OV strongly declined.

The "intranet" OV was much less represented over the period studied, whose predominant discourse pinpointed prospective applications. In 1999 and 2000, the notion of 'chaos' became highly recurrent.

Lastly, the "wireless" OV was at its apogee in 2000, to later decline. Whereas in 2001 the discourse was centred on the potential benefits and savings associated with this technology ("save big bucks by going wireless"), in 2002 it evolved to converge on wireless security and risk issues ("runs security tests on wireless LANs", "new risk for wireless access points').

\section{Organizing Visions: the Perspective of Informationweek}

Likewise, a lexical analysis on the most frequently-used words was performed on Informationweek magazine over the same 1999-2003 period. It highlighted a number of points: 
- Similar developments in comparison with Computerworld:

- The issue of security is equally present this magazine. Relatively, the keyword "security" comes in second place in the years 2002 and 2003. In absolute terms, the frequency of this keyword's occurrence increased from 1999 to 2000, stagnated at the same level in 2000-2001, to then drop off beginning in 2002.

- Management discourse surrounding the notion of "collaboration" emerged on a significant degree in 2001 , to then disappear.

- 1999 and 2000 witnessed the climax of numerous technological concepts such as web ', 'Internet businesses, CRM, ERP.

- High presence of IT business players, with an even greater variety than in Computerworld.

The below graph highlights the tracking of the five technological concepts selected with regards to the frequency of appearance.

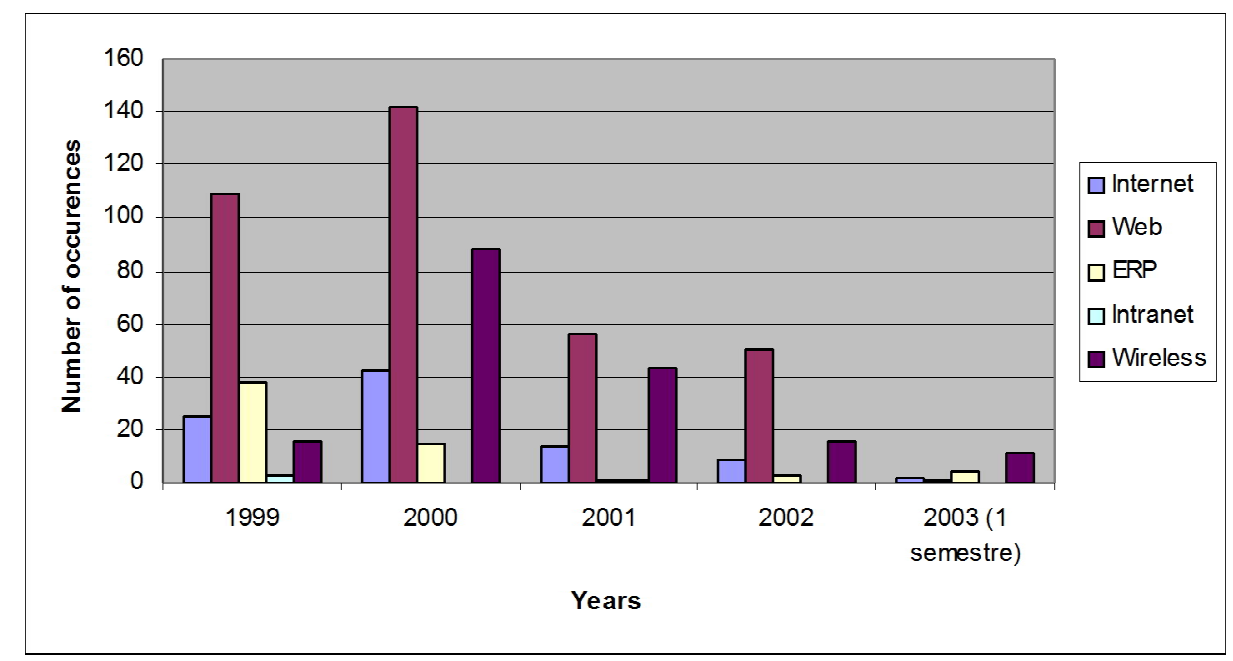

Figure 3: Tracking the Five selected Technological Concepts in Informationweek

A pivotal analysis on the five keywords selected led us to expand our understanding of the discourse conveyed by this magazine:

The "Internet" OV was at its pinnacle in 2000. If, in 1999, the article titles examined underscored its applications in the telecoms industry, by 2000 , it began 
focusing rather on two specific areas: the Internet's potential applications in several sectors (such as banking and customs/immigration), as well as its economic prospects ("the internet's true benefits"). In 2001 the rapid decline of the Internet OV corresponds to a more pessimistic discourse in such publications "the end of internet time") to finish, in 2002, with a more legally-oriented language based on the larger issue raised by the advent of this technology.

As for the concept "web", the frequency of occurrence evolved in a manner like that of the 'internet' OV, to nevertheless a much greater degree. At its peak in 2000, media discussion was mainly focused on the web's added value ("better performance guarantees ", "web hosts offer broader services and capabilities ") as well as on its new services offered ("voice messaging on the web ", "get personal with web marketing ", "teamwork via the web"). In 2001 and following on into 2002, the term "webservices" and its correlates began to appear and was consistently associated with positive connotations (this trend is similar to what occurs in the magazine Computerworld).

Throughout the period studied, the "ERP" OV declined. In 1999 the vast majority of titles were linked to its potential applications, and it further developed in 2000 to embrace the notion of online ERP. Over the entire period, following the example of Computerworld, a good many titles deal with the struggles faced by market players (fierce combat, competitor's edge, etc...).

Frequency of occurrence for the "intranet" keyword was remarkably low over the period studied. At the beginning (1999), one found a prevalence of performance-related speech (economic assessment, or $\mathrm{ROI}$ ) as well as commentary on the ongoing interface between the HTML and XML protocols.

The "wireless" OV was at its apogee in 2000. From 1999 to 2002, the discourse tended to be positive ("wireless systems to the rescue" en 2002) and turned to security issues ("protect wireless LAN's", "west point secures wireless $L A N$ ", "area to create wireless public-safety network" en 2002). In 2003, the future of this concept was subject to question: "Will 2003 be the year of wireless LANs?"

Likewise, the thematic analysis based on Informationweek provides an interesting point of view to the lexico-metric analysis (see figure 4). It revealed a significant level of 
stability in terms of the discourse surrounding strategy and business policy on the main IT players (on average one-quarter of all articles, see for example POL-CA). Moreover, the impact of the "new" economy's lag in France became obvious. Titles witnessed an increased interest in both jobs (EMP) as well as in more in-depth articles dealing with the economic conditions of IT players and their customers (ESE). Contrary to what we actually expected, magazine assessment of products and technological concepts were more abundant at the peak of the "new economy" and later declined. Conversely, articles based on the alignment of technology with the organization, as well as technology-user relations, became increasingly frequent, focusing on specific cases that induce the authors to assume a more normative approach to technology use in general.

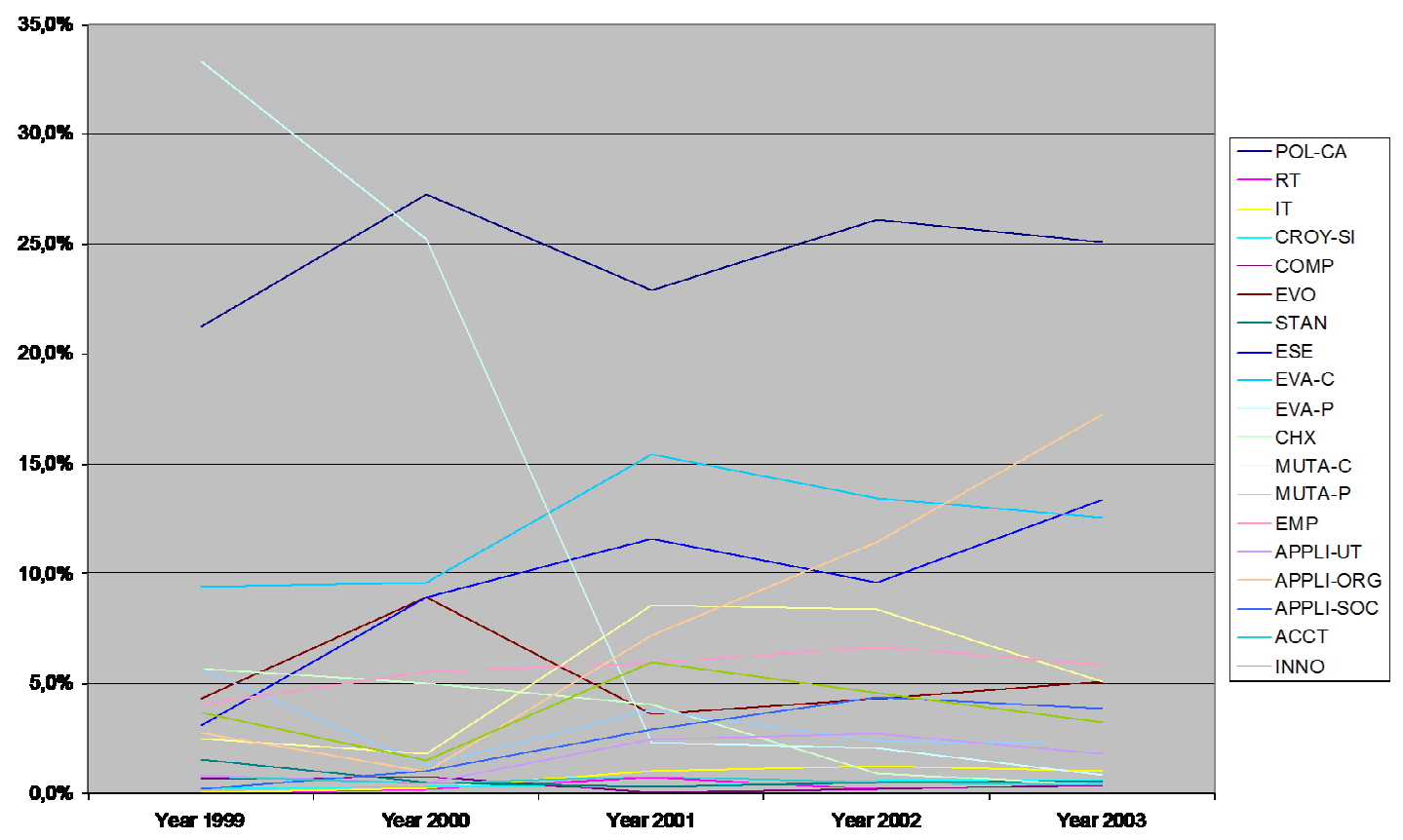

Figure 4: Informationweek: Evolution of selected themes from 1999 to 2003 (For a complete description, definition and examples of the different acronyms, see appendix A.1.2.)

When the analysis moves beyond a given theme, we notice that articles published in Informationweek have short, arresting titles, based on a very limited use of metaphors (as opposed to French magazines, which we will examine later). The content is often extra-practical and rarely conceptual. American magazines generally make explicit references to a product or a type of product rather than to a generic concept such as ERP, Intranet, CRM or e-business software. 


\section{The Organizing Vision of 01 Informatique}

The French magazine 01 Informatique demonstrates a number of notable trends:

- A significant frequency of management keywords and IT vocabulary (company, tool, business, service, training, competencies, market, jobs, SME...),

A strong domination of Internet-linked themes up to 2000, with its progressive slowdown over the next three following years,

- The appearance of the CIO concept and IS global management in the years 2002 and 2003, based on keywords like CIO. On the opposite side, the notion of IT analysts and developers demonstrated a slowdown from 2000 to 2003.

More precisely, the below graph focuses on the network-based technology OV.

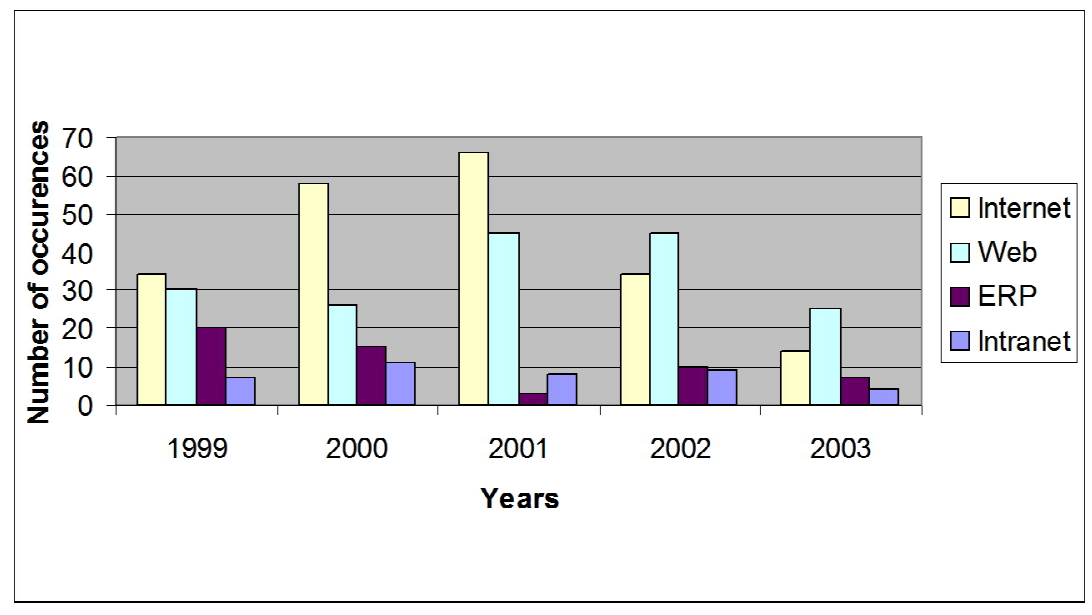

Figure 5: Evolution of four keywords in 01 Informatique

We notice both an ending cycle for the Internet OV, as well as a discontinuous decline for the ERP OV could be noticed. The Intranet concept remains moderately present in publications. We equally observe the appearance of a new OV dealing with wireless networks (Wi-Fi technology) that seems to follow a longer lifecycle than the Wap technology.

Looking at pivots and themes associated with the different OVs, our results prove to be equally pertinent. Through the pivot analysis conducted, we discovered a broad 
and general lexical field as far as the Internet OV is concerned. This OV's technological potential and affinities seemed endless in 1999 and 2000, to end in 2002 and 2003 with a more business and technological concept-oriented terminology ("access", "new perspectives", "communicate", “EDI", "outsourcing", "recruitment"...). In the years 1999, 2000 and 2001, the pivot analysis on the Intranet OV underscores that implementation is based more and more on support processes ("communicate", "inform", "wait"). Concerning the ERP OV, we note a dual trend over the four years studied: the emergence of a high degree of scepticism about implementation and the tool's added value, as well as the search for business opportunities. Finally, the Wi-Fi OV makes a marked entry from the beginning of late 2002, initiating a trend that may have been confirmed in 2003 (for the first two quarters, we already noticed 14 occurrences for the term).

\section{Organizing Vision in Le Monde Informatique (LMI)}

Generally, LMI magazine is focused as much on management discourse as 01 Informatique magazine (see Appendix A.1.). Management keywords are as numerous as are IT keywords. More precisely, if we look at network technology-based OVs, we witness the following occurrences:

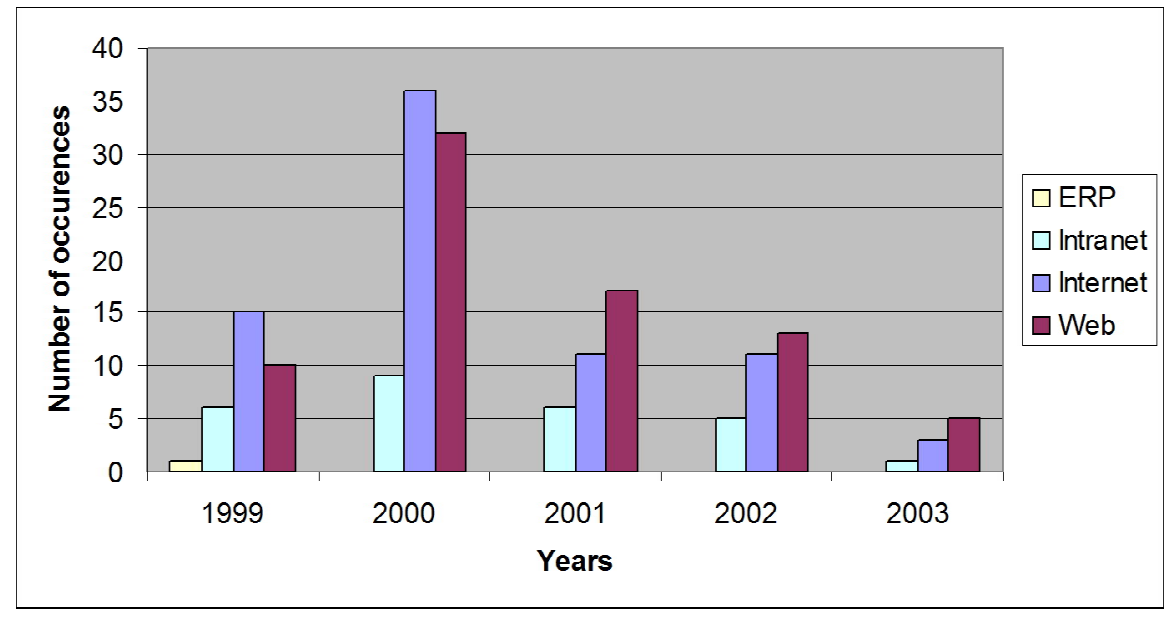

Figure 6: Evolution of four keywords in Le Monde Informatique

The pivot analysis confirms a number of trends emphasized, starting with the 
analysis of 01 Informatique. Thus in 1999, keywords associated with Internet are predominantly sales-oriented ("ads", "advertisement", "clientele", "creation", "marketing"...) and the discourse is positive, whereas in 2000 , the lexical field was much more diversified (political, legal, managerial or technical aspects) with, at times, a tendency to make more negative assertions. In 2001, we sensed a true need for reassurance. The topics associated with the Net became centred again on business and management aspects. Categorically pessimistic claims nevertheless appeared. This reflects a reticent market and a cautious position. Beginning in 2002, the language turned positive: less ambitious than before, the discourse is more centred on precise concepts and practices. For the Intranet in 1999 and 2000, the feedback on its implementation grew with an emphasis on its practical aspects. The particular cases of a number of multinationals (Lagardère, Atos Origin, ASF...) were cited in 2000. The speech here was clearly tied to management-oriented practices (quality, communication, decision-making, HR...) and appears to be inductive, in other words, the approach moves from practice towards theory and not vice-versa. This trend seems to have persisted over the period 2001-2002, with a progressive convergence towards other technological concepts such as portals, ERP, or e-business. For the ERP concept, the years 2000-2003 demonstrate the arrival of an increasingly critical discourse on ERP's flexibility, added value, or management modes. For the year 2003, we notice a drop in the number of occurrences, as well as a more positive discourse, i.e. referring to a success story, the arrival of a "new wave of ERP projects", etc. But it was still a little premature at that time to speak of an ERP "revival". To finish, Wi-Fi technologies appeared on the horizon in 2002, but their arrival is more subdued than in 01 Informatique, for example.

\section{The Organizing Vision based on French Trade Fairs and Professional Organizations}

A number of IS Design and Management-oriented colloquia and national professional organizations exist in France (for the period under study). One can mention the "Club Informatique des Grandes Entreprises Françaises" (CIGREF: The IS Club for large French corporations", the IS and Telecommunications Press Club (that organizes 
meetings between players in the IT sector and the press), the SYRPIN (Syndicat régional des prestataires informatiques, a regional union for IT services providers), the IS Proficiency Association (I'ADELI). Some associations have a regional dimension, such as the 'Digital Circle' in Toulouse or the ICT Agency in Burgundy that fosters general relations between public interests (such as Chambers of Commerce) and private interests. Thus, they often have a societal message to communicate, such as "raising awareness in IT user companies" in the case of the ICT Agency in Burgundy. Along these same lines, the national associations promote a more activist message, such as in the case of the National IT Consultants Unity Movement, MUNCI).

Some French national structures are explicitly focused on SMEs, such as the very recently formed 'e-business club' or the 'Richelieu Committee'. These remain, however, in the minority.

The structures that we have identified are generally national ones that are focused on large companies (a typical case is the CIGREF). Some hire experts on an assignment basis in order to regularly produce reports and analyses. Each one demonstrates its own specific field of expertise. In most cases, we observe a moderate presence of the major business players. Some are open to non-corporate IS communities (such as Adeli which is open to educators, for example).

Surprisingly, we have identified very few opportunities and locations for exchanging information on "best practices" (regional or by sector) that would be facilitated by practitioners, for practitioners.

\section{The Organizing Vision based on American Trade Fairs and Professional Organizations}

There is a great number of IT-related American trade fairs and professional organizations (SIMposium, AITP, CCIA, TICA...) and some possess a dimension that goes far beyond what exists in France, such as the CPSR.

Over the period 1999-2002, these organizations were closely linked to the main business players from the IT field. We equally found a systematically regional set-up for these groups, in the form of local and regional clubs, as well as the organization of 
numerous regional events. Member profiles are quite diversified and go from tiny startups to large multinationals. Even the association for players in the Telecommunications Sector (the Telecommunication Industry Association, TIA) is open to industrial SMEs as well as large companies.

Among those in charge of such groups, one almost never encounters dedicated assignments for conducting specialized studies, which are prevalent in France. Most of the time, these jobs are managed by IS managers or consultants. Group discussions deal primarily with specific products and applications, and less with generic technological concepts. The discourse is generally less conceptual and the evaluation is centred on $\mathrm{ROI}$ and 'best practices' exchanges linked to individual tasks and job proficiencies.

We did not find an equivalent to the French IS and Telecommunications Press Club. There are no specific forums where practitioners and press members can meet, but rather the aforementioned, more generalized IT conferences and events.

In terms of topics, when we look more specifically at events, such as conferences, over the period studied, we observe trends quite similar to those identified in the IT press: security concerns (equally present today, i.e. Interop 2005), a high level of enthusiasm for e-business in 1999, a high degree of complicity between major business players, etc.

\section{CRITICAL COMPARISON}

The below table illustrates the main differences between France and US:

Table 3: OV Comparison, France-U.S., 1999-2003

\begin{tabular}{|l|l|l|}
\hline & \multicolumn{1}{|c|}{ FRANCE } & \multicolumn{1}{|c|}{ UNITED STATES } \\
\hline $\begin{array}{l}\text { Organizing meta-vision of the } \\
\text { period 1999-2003 }\end{array}$ & $\begin{array}{l}\text { Open network technologies } \\
\text { Importance of cross- } \\
\text { organizational IS }\end{array}$ & $\begin{array}{l}\text { Network technologies and cross- } \\
\text { organizational IS, but in a very } \\
\text { compartmentalized and security- } \\
\text { oriented framework }\end{array}$ \\
\hline $\begin{array}{l}\text { Most frequently encountered } \\
\text { concepts over the 1999-2003 }\end{array}$ & $\begin{array}{l}\text { Web, electronic commerce, Wi-Fi } \\
\text { (latter part of period) }\end{array}$ & $\begin{array}{l}\text { Security, web, on-line } \\
\text { commerce, business players, }\end{array}$ \\
\hline
\end{tabular}




\begin{tabular}{|c|c|c|}
\hline period & & collaborative technologies \\
\hline $\begin{array}{l}\text { Concepts at the end of their } \\
\text { life cycle during the } 1999-2003 \\
\text { period }\end{array}$ & $\begin{array}{l}\text { Internet technologies, Integration } \\
\text { (ERP), Wap }\end{array}$ & $\begin{array}{l}\text { Internet technologies, ERP, Wi- } \\
\mathrm{Fi}\end{array}$ \\
\hline Profile of the lexical dynamics & $\begin{array}{l}\text { Descending for Internet } \\
\text { technologies, ascending and } \\
\text { descending for the Wi-Fi } \\
\text { keyword } \\
\text { General } \\
\text { enhancement/enrichment of OV } \\
\text { (to the detriment of its } \\
\text { consistency) }\end{array}$ & $\begin{array}{l}\text { Same here, but perhaps greater } \\
\text { consistency due largely to the } \\
\text { security obsession which } \\
\text { systematically provides a } \\
\text { reference point for locating and } \\
\text { assessing new technological } \\
\text { concepts } \\
\text { An equally strong presence } \\
\text { among pivots of the main } \\
\text { business players significantly } \\
\text { involved in the agency between } \\
\text { the various OVs. }\end{array}$ \\
\hline
\end{tabular}

In both cases, we perceive an implicit reference to a large meta-OV linked to network technologies (with the wave of Internet technologies and integration tools). Yet we note some national specificities, particularly with security matters. We may thus underscore that $9 / 11$ for the US was more a catalyst for the security obsession than a causal factor.

Beyond a strictly thematic comparison, the comparative analysis of the institutional players, as well as the editorial policies of the magazines studied in our analysis, equally suggest that OV creation modes are in fact country-specific.

In the French case, the OV is created through the interaction between local communities of practice (often linked to large companies) and a meta community of practice that intermingles certain local players with specialized ones. Forums linked to the meta-OV are, from the very start, national. We noticed very few local relay points. The numerous institutional players not linked to local communities of practice (project heads, experts, analysts, IS auditing consultants, researchers, academics, governmental consultants, etc.) actually enrich the OV discourses, as well as the related reflexive processes. The main business players are also present but only moderately.

In the case of the US, the forum in which an OV is produced is more akin to a large, barrier-free market that integrates numerous local or national players, as well as the main business players. The whole forum is focused on 'best practices' exchanges, 
based on products or a range of products, rather than on broad technological concepts. The main concerns one encounters here are more oriented towards the short term than the long term. The institutional production of the $\mathrm{OV}$ is directly rooted in an organization's IS practices, and in the fierce competition which is played out among the IT market's main players.

\section{LONGITUDINAL STUDY OF AN OV'S CAREER PATH IN FRENCH AND AMERICAN ORGANIZATIONAL CONTEXTS}

After having carried out a study on the various institutional environments in organizations and their links to technology, we shall now take a look at micro-social practices, as well as their connections to cross-organizational representations. We will begin with a presentation of the methodology, as well as a summary of meta-analyses of French and American cases over the period studied (1999-2003). We will focus specifically on what we designate as each organization's appropriation profile, as well as its receptivity to societal discourses. We will then propose an analysis of an OV's career in relation to the cases studied. Lastly, we shall summarize by proposing some typical models for the dynamics of OV appropriation.

\section{METHODOLOGY USED}

\section{Case Studies Selection Process}

We broadened the scope of the selection process to include periodical publications, French and American research colloquia whose case studies target concepts such as the intranet; ERP, e-business, etc. We equally attempted to include specific activity sectors, such as the Environmental, banking or Healthcare industries. These sectors were targeted because the authors have carried out longitudinal French case studies in these sectors. They were thus familiar with their history and key-actors. The selection criteria were as follows:

-Case study's assessment of concept over a continuous period, necessarily 
between 1999 and 2003;

-Minimal social interaction analysis in the case study;

-Contextually relevant to either the American or French environment in which it is situated.

The various cases selected are presented in Appendix A.2.

\section{Data Reduction and Analysis}

Two tables have been created (see appendix A.2 and table 4) in order to compare the different appropriation trajectories for each of the concepts studied. It has enabled us to describe, among others:

- $\quad$ Case study's title and authors;

- Description of the system implemented (which necessarily uses one of the technologies targeted);

- $\quad$ OV building blocks identified during the period;

- $\quad$ Convergence of the above-named building blocks with the OV's various aspects (reproduction, transformation, reinforcement).

\section{CROSS-CASE ANALYSIS}

The case analysis was aimed at capturing local discourses dealing with technological implementation as well as at comparing these local discourses with previous OV identified through content, pivot and lexicometric analysis. Details for each case about IS main features and socio-technical dynamics are presented in appendices A.2.1 and A.2.2. The table below sums up the articulation between local and macro levels for each longitudinal case.

Table 4 : American cases and OV dynamics

\begin{tabular}{|c|l|l|}
\hline \multicolumn{1}{|c|}{ Case } & \multicolumn{1}{c|}{ Relationship with OV dynamic } \\
\hline $\mathbf{1}$ & $\begin{array}{l}\text { [Doolan and al. 2003]; } \\
\text { [Gardner and al. 1999] }\end{array}$ & $\begin{array}{l}\text { Reproduction of OV: } \\
\text { The developments in the 1999-2003 period show a will to implement some } \\
\text { OV elements/or a sharing of some ideas corresponding to the OV; a will to }\end{array}$ \\
\hline
\end{tabular}




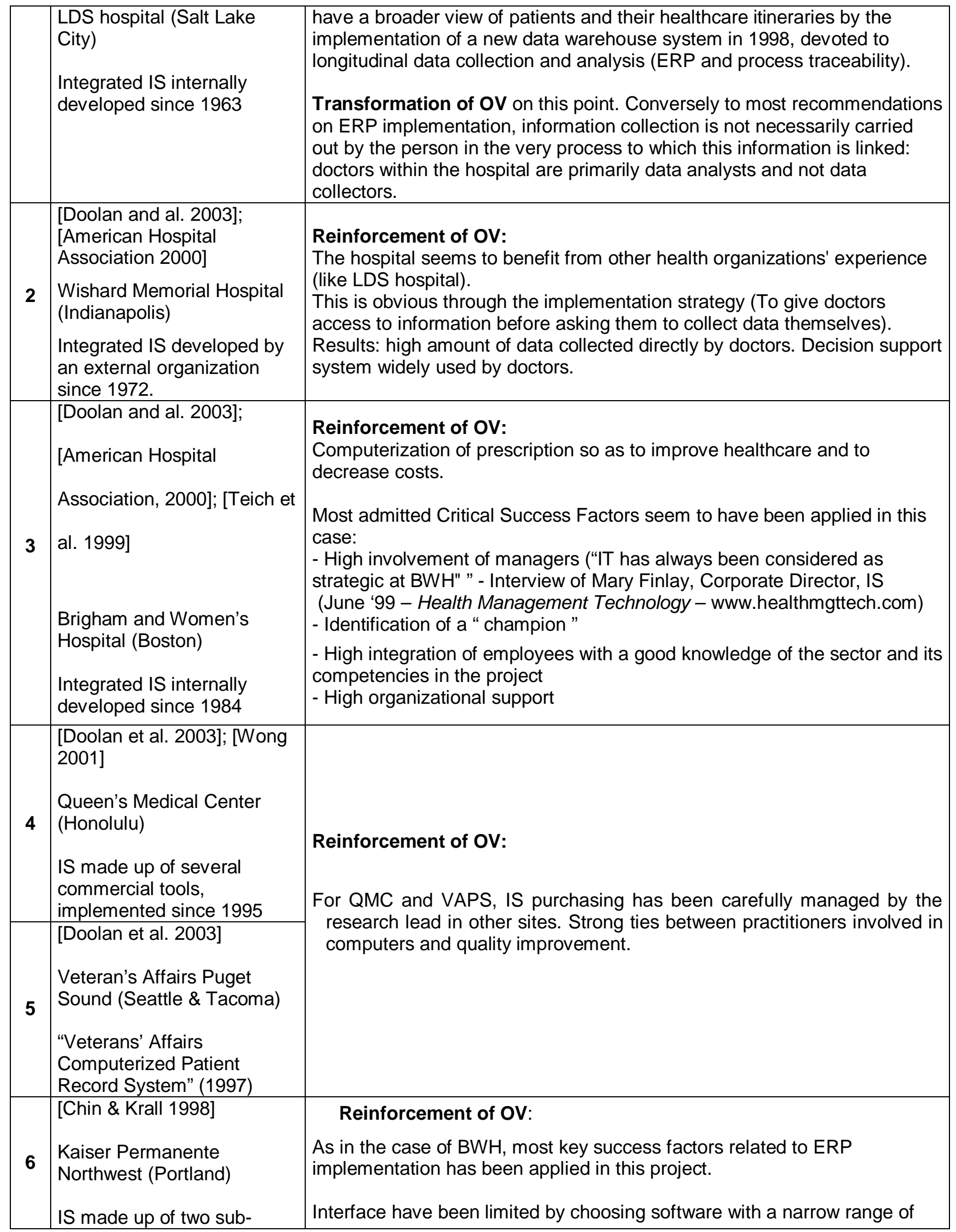




\begin{tabular}{|c|c|c|}
\hline & $\begin{array}{l}\text { systems: a results reporting } \\
\text { system (1990-1998) and a } \\
\text { clinical IS, highly integrated } \\
\text { (1994-1998) }\end{array}$ & $\begin{array}{l}\text { interface } \\
\text { IS vertically integrated, in order to limit the number of different solutions }\end{array}$ \\
\hline 7 & $\begin{array}{l}\text { [Marchioni 2001] } \\
\text { U.S. Bureau of Labour } \\
\text { Statistics } \\
\text { Adoption of the Internet and } \\
\text { WWW-based user interfaces } \\
(1996-2001)\end{array}$ & $\begin{array}{l}\text { Very few elements related to the OV in this case. } \\
\text { No reference to any inter-organisational or societal tendencies in this case. } \\
\text { No exploitation, adaptation or transformation of authorised } \\
\text { discourses. }\end{array}$ \\
\hline 8 & $\begin{array}{l}\text { [Majchrzack, Rice, Malhotra } \\
\text { and King 2000] } \\
\text { Implementation of a } \\
\text { collaborative technology } \\
\text { (1999) }\end{array}$ & $\begin{array}{l}\text { Describe an adaptation process of a technology in an unusual } \\
\text { environment, a virtual work group } \\
\text { Avoidance of OV's ideas. } \\
\text { Adoption related to an enacted market-pressure. } \\
\text { Iterative project that implied several successive re-organizations }\end{array}$ \\
\hline 9 & $\begin{array}{l}\text { [Ash, Burn 2003] } \\
\text { Project linking an ERP and } \\
\text { an e-business system } \\
(1999-2000)\end{array}$ & $\begin{array}{l}\text { Reproduction of the OV: the adoption has been pushed by IT department } \\
\text { leader in the firm. They have sold the project "in order to sale a new image } \\
\text { of the firm" } \\
\text { P 382: Then, in order to sale the project internally, leaders have shown the } \\
\text { link between the project and firm's strategic objectives. }\end{array}$ \\
\hline 10 & $\begin{array}{l}\text { [Hughes, Stone 2002] } \\
\text { Implementation of a website } \\
\text { for professional customers } \\
\text { in two firms (banking) } \\
(1999-2000)\end{array}$ & $\begin{array}{l}\text { Case 1: the director, highly technology oriented (p. 386) pushed to quickly } \\
\text { develop the project, but forgot to } 1 / \text { study the project in committees and } 2 / \\
\text { analyses the procedures. Gave priority to this development instead of to } \\
\text { other activities. High degree of internal debate/general reflection on the } \\
\text { topic. } \\
\text { On the whole, reproduction of the OV related to that kind of technology. } \\
\text { Case } 2: \text { the e-business project experienced strong practical and cultural } \\
\text { barriers (p. } 385) \text {. Thus, the project was focused on an internal reflection. } \\
\text { Lastly, the project narrowed its perimeter and expanded the deadlines. On } \\
\text { the whole, ideas related to the OV have been circumvented. }\end{array}$ \\
\hline 11 & $\begin{array}{l}\text { [Mieczkowska, Barnes, } \\
\text { Hinton 2002] } \\
\text { E-commerce (customer } \\
\text { information feedback)) } \\
(1999)\end{array}$ & $\begin{array}{l}\text { Reinforcement of the OV: } \\
\text { "It seems that the adoption of e-commerce in these companies has been } \\
\text { largely technology-oriented" ( } p \text { 189). Firms perceive a threat of the } \\
\text { competition, and a desire to be at the same level than other doing e- } \\
\text { commerce. }\end{array}$ \\
\hline 12 & $\begin{array}{l}\text { [Kapp 2001] } \\
\text { e-catalog for customers, } \\
\text { enabling multi-criteria } \\
\text { research } \\
(2000)\end{array}$ & $\begin{array}{l}\text { Avoid the OV: } \\
\text { Before choosing a technology, a precise study of internal process, then } \\
\text { internal reorganisation, and lastly automatization processes were } \\
\text { implemented, thanks to e-catalog implementation "the software must not } \\
\text { be chosen because it offers numerous functionalities, but because it } \\
\text { performs the expected work" p.64 }\end{array}$ \\
\hline
\end{tabular}

Table 5:French cases and OV dynamics

\begin{tabular}{|c|c|c|}
\hline $\mathbf{N}^{\circ}$ & \multicolumn{1}{|c|}{ Case } & \multicolumn{1}{c|}{ Relationship with OV dynamic } \\
\hline a & {$[$ Romeyer 2001] } & $\begin{array}{l}\text { OV ideas are not integrated by members of this organization. Indeed, they } \\
\text { decide to implement an un-integrated application in a context where ERPs }\end{array}$ \\
\hline
\end{tabular}




\begin{tabular}{|c|c|c|}
\hline & $\begin{array}{l}\text { Implementation of patient- } \\
\text { processing IS over the } \\
1997-2000 \text { period }\end{array}$ & $\begin{array}{l}\text { are heavily taken into account. } \\
\text { Surrounding discourses on IT being implemented is not representative of } \\
\text { the core communication - quite the contrary in fact. } \\
\text { Choices made during the project are related to internal dynamics } \\
\text { (experiments conducted by the organization) rather than 'authorized' ideas, } \\
\text { e.g. OV. }\end{array}$ \\
\hline b & $\begin{array}{l}\text { [de Vaujany 2001, 2003] } \\
\text { Intranet implementation in } \\
\text { big French firms (1999- } \\
\text { 2001) }\end{array}$ & $\begin{array}{l}\text { We largely find a reproduction of most of the Intranet OV's elements in } \\
\text { the firm's internal communications, and in the discourse of most frequently- } \\
\text { interviewed IS managers. } \\
\text { The OV here is a driver of initial investment. } \\
\text { Appropriation dynamics are nevertheless far from the OV prescriptions. }\end{array}$ \\
\hline C & $\begin{array}{l}\text { [Chetioui Ben Osman L. } \\
2004] \\
\text { e-business (customer } \\
\text { services on line) in banking } \\
\text { activities } \\
(1999-2001) \\
\end{array}$ & $\begin{array}{l}\text { Reproduction of authorized ideas (the project was heavily influenced by } \\
\text { external discourses). } \\
\text { 'Follower' strategy. }\end{array}$ \\
\hline $\mathbf{d}$ & $\begin{array}{l}\text { [Bourgeois Carton 1999] } \\
\text { Electronic product catalogue } \\
\text { in a Large French group } \\
\text { involved in energy activities } \\
(1994-2003)\end{array}$ & $\begin{array}{l}\text { Reproduction of authorized ideas. } \\
\text { The project was promoted internally by relying in externally discourses. } \\
\text { Leader strategy. }\end{array}$ \\
\hline $\mathbf{e}$ & $\begin{array}{l}\text { [Deltour 2003] } \\
\text { Intranet implementation in a } \\
\text { banking structure } \\
(1998)\end{array}$ & $\begin{array}{l}\text { No real elements of consultation related to societal or inter- } \\
\text { organizational drivers. }\end{array}$ \\
\hline $\mathbf{f}$ & $\begin{array}{l}\text { [Vaast and Benghozi 2000] } \\
\text { Intranet implementation in } \\
\text { different firms } \\
(1999-2000)\end{array}$ & $\begin{array}{l}\text { Some elements of a societal discourse on the boundary-crossing power } \\
\text { of Intranets. } \\
\text { Cases show in fact a reproduction and reinforcement of the structures } \\
\text { through the project and its usage. }\end{array}$ \\
\hline
\end{tabular}

In the French case as well as the American one, there is an obvious permeability between local practices and cross-organisational discourses.

More specifically, network-based tools (especially Intranets) are presented by IS players as barrier-reducing vectors of cross-functionality within the organization. In both national contexts studied, we find that contrary to the actual discourse on the subject, these tools are in fact appropriated by the organizations as tools for reproducing and reinforcing internal organizational boundaries.

All sectors of the economy (healthcare, environment, banking) were at the time entering into a phase of deep transformation, linked to the advent of the 'new' economy. In France, as well as in the United States, the 1999-2000 period is characterized by a particular anxiety over the market and timing. In France there was a fear of "missing the 
train", as they say there, and in the United States, this was manifested in its concern for market positioning (nationally, internationally, too little, too late). Business activity, particularly e-business, was especially concerned with this trend towards anxiety.

In any case, the projects or technological concepts are rarely connected to strategic concerns, key success factors, or organizational objectives. They are rather part of a logic of appropriation. This logic appropriates new concepts which are, in fact, mimetic models of previously existing ones, e.g. "ERPs decrease process cycle time, intranets break down internal barriers, CRM tools facilitate customer relations," etc. In both cases, this phenomenon unfortunately allows the company to actually circumvent its energy away from strategic projects on new technology implementation. There are, however, some real differences in this appropriation process between American and French organizations.

For the U.S., the representations used are more linked to endogenous, i.e. internal, perceptions gained from the immediate competitive playing field. For France, the representations are equally linked to the immediate competitive playing field, but not only. There are equal amounts of representations connected to societal and interindustry concerns. The dynamics behind the construction of the OV here therefore appear to be different between these countries. In France the OV's content seems to be generated more specifically along institutional lines, whereas in the U.S. the OV's content is greatly enriched through local visions.

In the narration of these cases, one also notes an interesting difference in the way technologies are presented. The French are often centred on technological concepts (ERP, tracking capability, Intranets...) while the American cases are more directly centred on specific products or product types. In other words, technologies are conceptualised to a greater degree in the French case than in the American one.

In general, these cases demonstrate another difference in the construction of the environment: the French IS managers make reference to international competition and to a 'lag' behind larger multinationals (namely American ones), whereas American 
companies generally act along a logic and trajectory towards greater autonomy, with leader-oriented strategies.

In the specific case of e-business tools (particularly those concerned with the OV over the period studied) the case studies designated by the keyword 'e-business' or 'electronic commerce' present, in both cases, what we call 'open' appropriation trajectories, in which external discourses influence the birth of the project. Nevertheless, it appears that the keyword 'electronic catalogue' in the American case follows a more autonomous trajectory, less open to the discourse of the specialized publications. In this case the external discourse is not relayed back inside the firm to better promote and 'sell' the project, which is the case in France.

For integration systems, particularly in the health-care sector, the cases demonstrate differences in format as well as in content. The American cases present success stories, the results of a long-term experience, which serve to legitimise the OV and encourage others to imitate this practice, whereas the French cases can be seen rather as failures. Generally, socially-oriented discourse is more present in American organizations than in French ones. The organization's communication thus takes on a broader potential to avoid and reduce mistakes (particularly medical ones).

\section{RELATIONSHIP BETWEEN REPRESENTATIONS AND PRACTICES FOR THE FRENCH AND AMERICAN CASES}

Arriving at the end of our inter-case analysis, it appears difficult at best to elucidate the general differences between the organizing visions studied, and we have found that it would undoubtedly be more relevant to develop analyses centred on sectors. The American health-care sector is one that presents significant differences from the French one.

We found two major forms of appropriation dynamics advanced by [Carton, de Vaujany and Romeyer 2003]: Open Dynamics and Autonomous Dynamics. (cf. below table). 
Table 5: Two Generic OV Appropriation Dynamics [Carton, de Vaujany and Romeyer, 2003].

\begin{tabular}{|c|l|l|}
\hline Type of Dynamic & \multicolumn{1}{|c|}{ AUTONOMOUS } & \multicolumn{1}{|c|}{ OPEN } \\
\hline $\begin{array}{c}\text { Dynamics of } \\
\text { Formation } \\
\text { Concerned }\end{array}$ & $\begin{array}{l}\text { Transformation or avoidance of OV's } \\
\text { ideas } \\
\text { Non-instrumentation }{ }^{1} \text { of authorised } \\
\text { discourses }\end{array}$ & $\begin{array}{l}\text { Reproduction and reinforcement of } \\
\text { OV (if the organizational whole is } \\
\text { considered at a societal level) } \\
\text { Some instrumentation of authorised } \\
\text { discourse }\end{array}$ \\
\hline $\begin{array}{c}\text { Organizational } \\
\text { Profile }\end{array}$ & $\begin{array}{l}\text { Belonging to a sector little concerned } \\
\text { with certain media fads } \\
\text { Leadership strategy in terms of } \\
\text { technological choices } \\
\text { A certain autonomy for the IS } \\
\text { component in comparison with other } \\
\text { organisational components } \\
\text { The vocation of IS Management is } \\
\text { one of expertise appearing distant to } \\
\text { other members of organisation }\end{array}$ & $\begin{array}{l}\text { Low-key IS strategy formation, } \\
\text { sometimes due to significant } \\
\text { divisions within organisational } \\
\text { structure (in terms of vocations, } \\
\text { foreign branches, geography, etc). } \\
\text { Guiding IT philosophy evolves more } \\
\text { according to sales trends than to a } \\
\text { long-term strategy } \\
\text { Function of IS relatively well- } \\
\text { integrated into the organisation }\end{array}$ \\
\hline
\end{tabular}

The France-U.S. comparison invites us to distinguish between open, broad-based dynamics and more targeted dynamics.

The open, targeted dynamics (American) are directly centred on the immediate competitive playing field as perceived by the organization. We are dealing with an OV broadly embedded in competitive games played between players in the sector and IT specialists. The OV's formation is here directly tied to the network of 'communities of practice' that come into contact.

The broad, open dynamics (French) are not only in tune with the competitive context but also with the larger economy as reflected by a system of OV formation and production which appears more dualistic than in the case of the targeted dynamics. This enables the players to estimate their performance (and lag) and to gauge themselves on a broader scale than their American counterparts (namely in terms of concepts like ebusiness and intranets).

\footnotetext{
${ }^{1}$ The term « instrumentation » means either exploitation, adaptation or transformation of the OV.
} 


\section{CONCLUSIONS: LIMITATIONS, ADDED-VALUES AND FUTURE PERSPECTIVES}

The above study is a first step in a research project that merits further reflection due to a number of limitations.

The players who are most involved in promoting OVs are absent from our study. A more exhaustive survey could be carried out in order to define the systems of institutional production for French and American OVs. Semi-directed interviews with active players in OV production (journalists, project heads, leaders in professional organisations, consultants, etc) could contribute usefully to this work in progress. Then, a content analysis of their discourse and that of IS medias may result in interesting similarities or differences.

Certain aspects of our data are under-exploited, and a number of complementary analyses could be conducted using our data. In particular, a factorial analysis could be carried out on the occurrence of keywords and themes, using the coding from Information Week and 01 Informatique (see on this Carton, de Vaujany and Romeyer, 2003). It would be particularly useful to review the thematic evolution across time, and how both become 'systematic' in the U.S. and France.

Certain working hypotheses contained here may seem reductionist, namely the lexicometric section which associated the frequency of a keyword's occurrence with an 'interest'. This assumption (which we found to be reasonable) could however be subject to debate and discussion. Interest does not always boils down to a frequency of citation.

Despite these limits, we think that this work opens up some interesting perspectives, particularly in the juxtaposition of field-based information and theories that do not come into contact often enough (IS institutionalist theories and intercultural management theories, etc). Further works may try to include performance variables, as in Wang (2003) work correlating reputation with performance and salaries. This would be a way to link OV research more directly to managerial actions. 
Lastly, in particular in the case of multinational IS firms, this reserve could serve to open things up for better understanding differences between national institutional environments. Trans-institutional elements of an Organizing vision may be thus an interesting target for future research.

\section{REFERENCES}

American Hospital Association (2000), AHA (Advanced Health in America) Guide to Computerized Physician Order-Entry Systems, report, November.

Ash C.G. and Burn J.M. (2003), "A strategic framework for the management of ERP enabled e-business change", European Journal of Operational research, vol 146, issue 2.

Carton S., de Vaujany F.X. and Romeyer C. (2003), "Le modèle de la Vision Organisante: un essai d'instrumentation", Systèmes d'Information et Management, vol. $8 n^{\circ} 4$, pp.3-29.

Chetioui Ben Osman L. (2004), "La constitution de l'innovation au quotidien: le cas de la banque sur Internet", Actes du colloque AIMS, Normandie.

Chin, H.L. \& Krall, M.A. (1998), "Successful Implementation of a Comprehensive Computer-Based Patient Record in Kaiser Permanente Northwest: Strategy and Experience", Effective Clinical Practice, vol 1, pp.51-60.

De Vaujany FX. (2001), Gérer l'innovation sociale à l'usage des technologies de l'information, une contribution structurationniste, thèse de doctorat en sciences de gestion, université Jean Moulin, Lyon 3, 438 p.

Deltour F. (2003), "Identification des leviers à l'usage d'un intranet: le cas d'une agence bancaire", colloque de l'Association Information et Management (AIM), Grenoble.

DIGITIP (2000), Les technologies de l'information et des communications et l'emploi en France (TIC\&EF), rapport publié par la Direction Générale de l'industrie, des Technologies de l'Information et des Postes (DIGTIP).

Di Maggio, P.J. and Powell W.W. (1991), The new institutionalism in organizational analysis, ch 1 introduction Chicago University press.

Doolan, D.F., Bates, D.W. \& James, B.C. (2003), "The Use of Computers for Clinical Care: A Case Series of Advanced U.S. Sites", Journal of the American Medical Informatics Association, vol. 10, n¹, jan-feb, pp. 94-107.

Firth DR. (2001), "The organizing vision for customer relationship management", ACIS 2001, proceedings.

Fomin V.V., McGann S.T., Lyytinen K.L. (2003) "Globalization and E-Commerce VII: Environment and Policy in the U.S." CAIS Volume 10 Article 8 November.

Fomin V.V., King J.L., Lyytinen K.L., Mc Gann S.T. (2005) "Diffusion and Impacts of ECommerce in the United States of America: Results from an Industry Survey" CAIS Volume 16 Article 28 October.

Gardner, R. M., Pryor, T.A., \& Warner, H.R. (1999), "The HELP hospital information system: update 1998", International Journal of Medical Informatics, vol. 54, pp. 169182. 
Hughes T. and Stone M. (2002), "The implications of e-commerce for strategy: UK case studies", Journal of financial services marketing, vol 6, n²4, pp. 379-390.

Kapp K.M. (2001), "A framework for successful e-technology implementation: understand, simplify, automate", Journal of Organizational Excellence, vol 21, issue, p.57.

Melka J. and Nayman L. (2003), "TIC et productivité: où est la France?" Lettre du CEPII, n²20, February 2003.

Mieczkowska S.M., Barnes D.L., Hinton C.M. (2002), "Finding fit: applications of B2B ebusiness in three UK insurance companies", Electronic Markets, vol 12, n³.

OCDE (2002), Measuring the information economy-ICT sector data.

Office Fédéral de la statistique (2003), Indicateurs de la société de l'information.

Romeyer, C. (2001), Système d'information fondé sur une traçabilité des activités : intérêt et difficultés de mise en ouvre dans les hôpitaux. Thèse de Doctorat en Sciences de Gestion à I'Université de la Méditerranée, Aix-Marseille II.

Swanson EB Ramiller NC (2003), "Organizing Visions for Information Technology and the Information Systems Executive Response", Journal of Management Information Systems, vol 20, n¹, pp. 13-50.

Swanson EB. and Ramiller NC. (2004), "Innovating mindfully with information technology", MIS Quarterly, Vol 28, n4, pp. 553-583.

Swanson EB. and Ramiller NC. (1997), "The organizing vision in information systems innovation”, Organization Science, Vol 8, n5, pp 458-474.

Teich, J.M., Glaser, J.P. et al. (1999), "The Brigham integrated computing system (BICS): advanced clinical systems in an academic hospital environment", International Journal of Medical Informatics, vol. 54, pp. 197-208.

Vaast E. and Benghozi P.-J. (2000), "Intranets et entreprises: technologie, apprentissages et organisation de la cohérence", Colloque de l'Association Information et Management (AIM), Montpellier.

Wang P. (2001), "What drives waves in Information Systems? The Organizing Vision perspective", Twenty-second International Conference of Information Systems, ICIS proceedings, pp. 410-416.

Wang P. and Swanson EB (2003), "Launching an Organizing vision: community entrepreneurship in Professional Services Automation", Academy of Management annual conference 2003, Proceedings.

Wang P. (2006) "The Organizational Impact of Information Technology Fashion" Twenty Seventh International Conference on Information Systems, Milwaukee

Whittington R. (2006), "Completing the Practice Turn in Strategy Research", Organization Studies, vol 27 n5, p.613-634

Wong, S (2001), "Electronic Health Records Implementation: Lessons we can learn from the pioneers", School of Health Information Science, August 16.

Yin RK. (1994), Case study research, Sage, second edition, first edition in 1989, 161 p. 


\section{Appendices}

A.1 Thematic and Lexico-metric Analyses

A.1.1- Thematic dictionary of French articles

\begin{tabular}{|c|c|c|}
\hline CATEGORY & DEFINITION & $\begin{array}{c}\text { EXAMPLES } \\
\text { (Our translation, } \\
01 \text { Informatique, 2002) }\end{array}$ \\
\hline -1- Technological Rupture [TR] & $\begin{array}{l}\text { Statements made on a new } \\
\text { technological concept presented } \\
\text { as a break from past/older } \\
\text { technologies }\end{array}$ & $\begin{array}{l}\text { GED is over, long live } \\
\text { documentary PGI } \\
P D A \text { is dead, long live PCA }\end{array}$ \\
\hline $\begin{array}{l}\text {-2- Technological Integration } \\
{[\mathrm{TI}]}\end{array}$ & $\begin{array}{l}\text { Statements made on one } \\
\text { technological concept include } \\
\text { another technological concept e }\end{array}$ & $\begin{array}{l}\text { Robotics walking away with new } \\
\text { IT innovations } \\
\text { Document Management turns to } \\
\text { Multimedia Files }\end{array}$ \\
\hline \begin{tabular}{|l|}
-3- IS Department \\
Management Practices [PGES]
\end{tabular} & $\begin{array}{l}\text { Discourse on IS Management } \\
\text { practices in terms of exploitation } \\
\text { (externalisation, maintenance, } \\
\text { project management) or } \\
\text { investment. }\end{array}$ & $\begin{array}{l}\text { DSI to face its organisational } \\
\text { model } \\
\text { IT management supervision } \\
\text { over-focused on spending } \\
\text { IT Management Financing e- } \\
\text { business Construction } \\
\text { One Internal IT Consultant } \\
\text { assigned to Each Business Unit }\end{array}$ \\
\hline $\begin{array}{l}-4-T e c h n o l o g i c a l \\
\text { Competition/Complementaritie } \\
\text { s } \\
\text { [COMP] }\end{array}$ & $\begin{array}{l}\text { Statements on competition } \\
\text { between two technological } \\
\text { concepts }\end{array}$ & $\begin{array}{l}\text { Cellular Telephones leaving } \\
\text { POTS (Plain Old Telephone } \\
\text { Service) in their dust }\end{array}$ \\
\hline $\begin{array}{l}\text {-5- Evolution of IT Sector } \\
\text { [EVO] }\end{array}$ & $\begin{array}{l}\text { Statements on the number of } \\
\text { competitors or on the IT Sector's } \\
\text { competitive structure }\end{array}$ & $\begin{array}{l}\text { European GPS Competition in } \\
\text { disorder } \\
\text { Be Editor Resigns }\end{array}$ \\
\hline -6- IT Market Outlook [CONJ] & $\begin{array}{l}\text { Comments on commercial } \\
\text { strength of a product or product } \\
\text { line }\end{array}$ & $\begin{array}{l}\text { Mediocre year for PC Sales } \\
\text { Virtual Cell Phone Operators: A } \\
\text { New Challenge for the Big Firms }\end{array}$ \\
\hline $\begin{array}{l}\text {-7- Standardisation and } \\
\text { Technological Coherence } \\
\text { [STAN] }\end{array}$ & $\begin{array}{l}\text { Statements on standardisation } \\
\text { procedures or implementation of } \\
\text { inter-operational processes }\end{array}$ & $\begin{array}{l}\text { All-Powerful Internet Gets put } \\
\text { back into Line } \\
\text { In Search of IT Standard for e- } \\
\text { cars/e-vehicles }\end{array}$ \\
\hline $\begin{array}{l}\text {-8- Corporate Financial } \\
\text { Behaviour [CPT] }\end{array}$ & $\begin{array}{l}\text { Statements on the quality of all } \\
\text { or part of an IT sector player's } \\
\text { performance }\end{array}$ & $\begin{array}{l}\text { Net Target plays with its clients' } \\
\text { profits }\end{array}$ \\
\hline \begin{tabular}{|l|}
-9- Evaluation of New \\
Technological Concept [EVA]
\end{tabular} & $\begin{array}{l}\text { Comments on a Technological } \\
\text { Concept's Technical, Economic, } \\
\text { or Social Added Value }\end{array}$ & $\begin{array}{l}\text { Automatic Scanning accelerates } \\
\text { healthcare data processing } \\
\text { High-Speed Networks re- } \\
\text { invigorate the Economy } \\
\text { Better off than its predecessors, } \\
\text { Windows XP still has a way to } \\
\text { go } \\
\text { New Internet Infrastructure will } \\
\text { facilitate Access and } \\
\text { Implementation }\end{array}$ \\
\hline $\begin{array}{l}\text { 10- Technological Choice of a } \\
\text { Player[CHX] }\end{array}$ & $\begin{array}{l}\text { Discussion of a particular choice } \\
\text { of information systems by a } \\
\text { particular player or of a type of }\end{array}$ & $\begin{array}{l}\text { Youth hostels place hopes on } \\
\text { software progress }\end{array}$ \\
\hline
\end{tabular}




\begin{tabular}{|c|l|l|}
\hline $\begin{array}{c}\text { 11- Transformation of a } \\
\text { technological concept } \\
\text { [MUTA] }\end{array}$ & $\begin{array}{l}\text { Statements on intrinsic } \\
\text { technological development of an } \\
\text { information system concept }\end{array}$ & $\begin{array}{l}\text { Ethernet passes from MAN to } \\
\text { WAN } \\
\text { The development tool: 100\% } \\
\text { Java }\end{array}$ \\
\hline $\begin{array}{c}\text { 12- Employment and skills in } \\
\text { IS [EMP] }\end{array}$ & $\begin{array}{l}\text { Comments on human-resource } \\
\text { aspects of the information } \\
\text { system profession }\end{array}$ & $\begin{array}{l}180,000 \text { computer scientists will } \\
\text { be recruited between now and } \\
2010 \\
\text { Network experts invited to be } \\
\text { managers }\end{array}$ \\
$\begin{array}{c}\text { 13- Application-finalization of } \\
\text { a technological concept (at } \\
\text { the organizational level) } \\
\text { [APPLI] }\end{array}$ & $\begin{array}{l}\text { Statements on the connection } \\
\text { between "technological concept } \\
\text { and organization" }\end{array}$ & $\begin{array}{l}\text { Thalès has one market place } \\
\text { per function } \\
\text { Benchmarking in the Internet } \\
\text { era }\end{array}$ \\
\hline $\begin{array}{c}\text { 14- Accompaniment of a } \\
\text { technological concept } \\
\text { [ACCT] }\end{array}$ & $\begin{array}{l}\text { Comments on socio-technical } \\
\text { aspects of the implementation of } \\
\text { an information system innovation } \\
\text { (training, communication, } \\
\text { technical adjustments) }\end{array}$ & $\begin{array}{l}\text { Guide to the implementation of } \\
\text { Installation of a SIG in a local } \\
\text { community }\end{array}$ \\
\hline $\begin{array}{c}\text { 15- Technological Innovation } \\
\text { [INNO] }\end{array}$ & $\begin{array}{l}\text { Assertions presenting a } \\
\text { technological tool in absolute } \\
\text { terms }\end{array}$ & $\begin{array}{l}\text { Knowledge Management } \\
\text { software }\end{array}$ \\
\hline
\end{tabular}

A.1.2 Thematic dictionary of American articles

\begin{tabular}{|l|l|l|}
\hline \multicolumn{1}{|c|}{ CATEGORY } & \multicolumn{1}{|c|}{ DEFINITION } & \multicolumn{1}{c|}{$\begin{array}{c}\text { EXAMPLES } \\
\text { (Infoweek 1998-2003) }\end{array}$} \\
\hline $\begin{array}{l}\text {-1- Technological break-down } \\
\text { [RT] }\end{array}$ & $\begin{array}{l}\text { Statements made on a new } \\
\text { technological concept presented } \\
\text { as a break from past/older } \\
\text { technologies }\end{array}$ & Will notebooks force out desktops? \\
\hline $\begin{array}{l}\text {-2- Technological Integration } \\
\text { [IT] }\end{array}$ & $\begin{array}{l}\text { Statements made on one } \\
\text { technological concept make } \\
\text { disappear another technological } \\
\text { concept }\end{array}$ & $\begin{array}{l}\text { Lotus Software Lets Developers Create } \\
\text { Portals. } \\
\text { CRM Vendors Wise Up To Business } \\
\text { Intelligence. }\end{array}$ \\
\hline $\begin{array}{l}\text {-3- Management practice of IS } \\
\text { departments [PGES] }\end{array}$ & $\begin{array}{l}\text { Discourse on IS management } \\
\text { practices related to exploitation } \\
\text { (externalization, maintenance, } \\
\text { project management) or to } \\
\text { investment }\end{array}$ & $\begin{array}{l}\text { Security Beyond Your Borders. } \\
\text { Security Efforts Could Use Some } \\
\text { Scientific Discipline. }\end{array}$ \\
\hline $\begin{array}{l}\text {-4- Belief with regard to IS } \\
\text { management [CROY-SI] }\end{array}$ & $\begin{array}{l}\text { Comments that deal explicitly with a } \\
\text { belief in IS management, from either a } \\
\text { critical or neutral perspective }\end{array}$ & $\begin{array}{l}\text { Not joust another Arthurian } \\
\text { E-mail myth debunked tale } \\
\text { Lexmark Shreds Paperless-Office Myth. }\end{array}$ \\
\hline $\begin{array}{l}\text {-5- Technological competition } \\
\text { [COMP] }\end{array}$ & $\begin{array}{l}\text { Comments on the competition or } \\
\text { the interplay between two } \\
\text { technological concepts }\end{array}$ & $\begin{array}{l}\text { Intel-Based Servers Get Ready To } \\
\text { Compete With Unix. }\end{array}$ \\
\hline $\begin{array}{l}\text {-6- Evolution of the structure } \\
\text { of the computer industry }\end{array}$ & $\begin{array}{l}\text { Comments dealing with the } \\
\text { number of competitors or }\end{array}$ & $\begin{array}{l}\text { It's The Battle Of The Web Browsers, } \\
\text { Redux. }\end{array}$ \\
\hline
\end{tabular}




\begin{tabular}{|c|c|c|}
\hline$[$ [EVO] & $\begin{array}{l}\text { competition structure in the } \\
\text { information system sector }\end{array}$ & \\
\hline $\begin{array}{l}-7-\text { Market situation of IS tools } \\
{[\text { CONJ] }}\end{array}$ & $\begin{array}{l}\text { Comments that deal with the } \\
\text { commercial strength of a product } \\
\text { or set of products }\end{array}$ & E-business slowly expands its horizon \\
\hline $\begin{array}{l}\text {-8- Technological } \\
\text { standardization and } \\
\text { coherence[STAN] }\end{array}$ & $\begin{array}{l}\text { Comments concerning } \\
\text { processes of standardization or } \\
\text { interoperability }\end{array}$ & $\begin{array}{l}\text { Extra layer: Web-services standard to } \\
\text { support security. } \\
\text { Network appliance backs new standard. }\end{array}$ \\
\hline $\begin{array}{l}-9-\text { Organizations' financial } \\
\text { behaviour [ESE] }\end{array}$ & $\begin{array}{l}\text { Comments on the financial } \\
\text { situation of an player in the IT } \\
\text { industry }\end{array}$ & $\begin{array}{l}\text { Accenture Forecasts Little Growth This } \\
\text { Year. } \\
\text { 3Com's Rough Quarter. }\end{array}$ \\
\hline $\begin{array}{l}-10-\text { Evaluation of a new } \\
\text { technological concept [EVA-C] } \\
\text { or a new product [EVA-P] }\end{array}$ & $\begin{array}{l}\text { Comments on technological, } \\
\text { economical or social added } \\
\text { values of an information system } \\
\text { concept }\end{array}$ & $\begin{array}{l}\text { ASP-s: they do more than just save } \\
\text { money. } \\
\text { ERP: it's not just for big companies }\end{array}$ \\
\hline $\begin{array}{l}\text {-11- Technological choice of } \\
\text { an actor }[\mathrm{CHX}]\end{array}$ & $\begin{array}{l}\text { Discussion of a particular choice } \\
\text { of information systems by a } \\
\text { player or a certain type of } \\
\text { economic player. }\end{array}$ & $\begin{array}{l}\text { Nissan Readies Wireless CRM For } \\
\text { Salespeople. }\end{array}$ \\
\hline $\begin{array}{l}\text {-12- Transformation of an } \\
\text { technological concept [MUTA- } \\
\text { C] or a product [MUT A-P] }\end{array}$ & $\begin{array}{l}\text { Assertions on intrinsic } \\
\text { technological development of an } \\
\text { information system concept }\end{array}$ & $\begin{array}{l}\text { Infolibria debuts new version of products } \\
\text { Idle PCs get put to work } \\
\text { CRM goes wireless } \\
\text { Business intelligence gets mobile and } \\
\text { gets personal }\end{array}$ \\
\hline $\begin{array}{l}\text {-13- Employment and skills in } \\
\text { IS [EMP] }\end{array}$ & $\begin{array}{l}\text { Comments on human-resource } \\
\text { aspects of the information } \\
\text { system profession }\end{array}$ & IT employment rate reach historic high \\
\hline $\begin{array}{l}\text {-14- Application-finalization of } \\
\text { a technological concept } \\
\text { (within a firm) [APPLI-ORG] }\end{array}$ & $\begin{array}{l}\text { Comments on the connection } \\
\text { between "technological concept } \\
\text { and organization" }\end{array}$ & $\begin{array}{l}\text { Treat IT projects like the investment they } \\
\text { really are }\end{array}$ \\
\hline $\begin{array}{l}\text {-15- Application-finalization of } \\
\text { a technological concept (from } \\
\text { a user's point of view) [APPLI- } \\
\text { UT] }\end{array}$ & $\begin{array}{l}\text { Assertions on the } \\
\text { interpretation/evaluation of a } \\
\text { technological concept from a user's point } \\
\text { of view }\end{array}$ & $\begin{array}{l}\text { Fade away from pesky calls, unwanted } \\
\text { mail. }\end{array}$ \\
\hline $\begin{array}{l}\text {-16- Application-finalization of } \\
\text { a technological concept (on a } \\
\text { societal scale) [APPLI-SOC] }\end{array}$ & $\begin{array}{l}\text { Discourse on the "technological concept- } \\
\text { society" articulation, i.e. about social } \\
\text { tendencies, legal or cultural trends in } \\
\text { technologies. }\end{array}$ & $\begin{array}{l}\text { Can IT bring some certainty back to this } \\
\text { quirky world? } \\
\text { IT Hiccups could slow down energy } \\
\text { deregulation in Texas }\end{array}$ \\
\hline $\begin{array}{l}\text {-17- Accompaniment of a } \\
\text { technological concept }[\mathrm{ACCT}]\end{array}$ & $\begin{array}{l}\text { Statements on socio-technical } \\
\text { aspects of the implementation of } \\
\text { an information system innovation } \\
\text { (training, communication, } \\
\text { technical adjustments) }\end{array}$ & $\begin{array}{l}\text { People Have To Come First. } \\
\text { 'How May I Help You?' Could Mean So } \\
\text { Much More. }\end{array}$ \\
\hline $\begin{array}{l}\text {-18- Technological innovation } \\
\text { [INNO] }\end{array}$ & $\begin{array}{l}\text { Comments that present a } \\
\text { technological tool in absolute } \\
\text { terms }\end{array}$ & Bit window arrives \\
\hline $\begin{array}{l}\text {-19- Commercial and strategic } \\
\text { policy [POL-CA] }\end{array}$ & $\begin{array}{l}\text { Discourse on the commercial offer and } \\
\text { more generally, the computer sector } \\
\text { players' strategy. }\end{array}$ & \begin{tabular}{|l|} 
Microsoft adopts $P 3 P$ in Internet Explorer \\
6.0 \\
Certicom targets wireless market \\
\end{tabular} \\
\hline
\end{tabular}

A.1.3 French Pivot analysis excerpts: $\mathbf{n b}: 2$. It refers to 2 words either side of the keyword 
* PGI (ERP), LMI 2000:

\begin{tabular}{|l|l|}
\hline \multicolumn{1}{|c|}{ Pivots -2 to-1 } & \multicolumn{1}{c|}{ Pivots +1 to +2 } \\
\hline Editeurs (editors) (1) & Communiquer (1) (Communicate) \\
\hline & Gestion (1) (Management) \\
\hline & Intégrer (1) (Integrate) \\
\hline & Mourir (1) (To die) \\
\hline & Obligé (1) (Compulsory) \\
\hline & Standard (1) (Standard) \\
\hline
\end{tabular}

* PGI (ERP), LMI 2002:

\begin{tabular}{|l|l|}
\hline \multicolumn{1}{|c|}{ Pivots $\mathbf{- 2}$ to $\mathbf{- 1}$} & \multicolumn{1}{|c|}{ Pivots $+\mathbf{1}$ to $+\mathbf{2}$} \\
\hline & Décor (1) (set) \\
\hline & Enfer (1) (Hell) \\
\hline & Fin (1) (End) \\
\hline & Frenchies (1) \\
\hline & Mythe (1) (Myth) \\
\hline & PME (1) (SME) \\
\hline
\end{tabular}

\section{* Internet, LMI 1999:}

\begin{tabular}{|l|l|}
\hline \multicolumn{1}{|c|}{ Pivots -2 to -1 } & \multicolumn{1}{c|}{ Pivots +1 to +2 } \\
\hline Pub (2) (ads) & Echappe (2) (Escape) \\
\hline Clientèle (1) (clientele) & Chercheurs (1) (Researchers) \\
\hline Dédale (1) (Maze) & Création (1) (Creation) \\
\hline EDI (1) (EDI) & Débit (1) (speed) \\
\hline Ere (1) (Era) & e- (1) \\
\hline Européen (1) (European) & Forme (1) (Shape) \\
\hline Géant (1) (Giant) & Graal (1) (Grail) \\
\hline Publicité (1) (advertisement) & Grande (1) (Big) \\
\hline Recruter (1) (Hire) & Haut (1) (High) \\
\hline Relation (1) (relation) & Laissez (1) (Let) \\
\hline Vitesse (1) (speed) & Marketing (1) (Marketing) \\
\hline & Masses (1) (Mass) \\
\hline & Mieux (1) (Best) \\
\hline & Paradis (1) (Paradise) \\
\hline & Peut (1) (Can) \\
\hline & Règle (1) (Rules)... \\
\hline & \\
\hline
\end{tabular}




\section{* Internet, LMI 2002:}

\begin{tabular}{|l|l|}
\hline \multicolumn{1}{|c|}{ Pivots -2 to -1 } & \multicolumn{1}{|c|}{ Pivots +1 to +2 } \\
\hline Client (1) (Customers) & Champ (1) (Field) \\
\hline Ecole (1) (School) & Débit (1) Speed \\
\hline Enfants (1) (Children) & Emploi (1) (Employment) \\
\hline Eveillez (1) (Wake up) & Formera (1) (will train) \\
\hline Faut (1) (Must) & Haut (1) (High) \\
\hline Internet (1) (Internet) & Ingénieurs (1) (Engineers) \\
\hline Lit (1) (Bed) & Mode (1) (Mode) \\
\hline Métier (1) (Job)... & Payant (1) (Paying)... \\
\hline
\end{tabular}

- Lexicometric Analysis Excerpts from Le Monde Informatique

\begin{tabular}{|c|c|c|c|c|c|}
\hline Years & 1999 & 2000 & 2001 & 2002 & 2003 \\
\hline Key word 1 & $\begin{array}{l}\text { Company/compani } \\
\text { es (17) }\end{array}$ & $\begin{array}{l}\text { Company/compani } \\
\text { es (56) }\end{array}$ & $\begin{array}{l}\text { e- (20), Company } \\
\text { (20), Computer } \\
\text { science (20) }\end{array}$ & $\begin{array}{l}\text { e- (23), } \\
\text { Company/compani } \\
\text { es (23) }\end{array}$ & Company (18) \\
\hline Key word 2 & $\begin{array}{l}\text { Management (15), } \\
\text { Internet (15) }\end{array}$ & $\begin{array}{l}\text { Computer science } \\
\text { (39) }\end{array}$ & Line (17), Web (17) & $\begin{array}{l}\text { Management (22), } \\
\text { Computer science } \\
\text { (22) }\end{array}$ & Computer science (12) \\
\hline Key word 3 & $\begin{array}{l}\text { Year } 2000(Y 2 K) \\
(13)\end{array}$ & Internet (36) & $\begin{array}{l}\text { Job (13), Company } \\
\text { (13), Market (13) }\end{array}$ & France (16) & $\mathrm{ClO}(9)$ \\
\hline Key word 4 & $\begin{array}{l}\text { Computer science } \\
\text { (13) }\end{array}$ & e- (33) & $\begin{array}{l}\text { France (12), } \\
\text { Computer scientists } \\
\text { (12), Security (12), } \\
\text { Software and IT } \\
\text { Services Firms (12) }\end{array}$ & $\begin{array}{l}\text { Security (14), } \\
\text { Service (14) }\end{array}$ & $\begin{array}{l}\text { Information (8), } \\
\text { Security (8) }\end{array}$ \\
\hline Key word 5 & $\begin{array}{l}\text { Computer scientists } \\
\text { (10), Web (10) }\end{array}$ & Web (32) & $\begin{array}{l}\text { Euro (11), Internet } \\
(11, \text { Sites }(11)\end{array}$ & Web (13) & $\begin{array}{l}\text { Management }(7) \text {, } \\
\text { softwares (7), source } \\
(7), \text { XML (7) }\end{array}$ \\
\hline Key word 6 & Commerce (9) & Line (26) & $\begin{array}{l}\text { Information (9), Net } \\
(9) \text {, Services (9) }\end{array}$ & $\begin{array}{lr}\text { Client } & (11), \\
\text { Internet } & (11), \\
\text { Software and IT } \\
\text { Services } & \text { Firms } \\
(11), & \end{array}$ & $\begin{array}{l}\text { Data (6), Open (6), } \\
\text { SME (6), Projects (6), } \\
\text { Services (6) }\end{array}$ \\
\hline Key word 7 & e- $(8)$ & Net (25) & $\begin{array}{l}\text { Training (8), } \\
\text { Management (8) }\end{array}$ & $\begin{array}{l}\text { HP (10), Net (10), } \\
\text { SME (10) }\end{array}$ & $\begin{array}{l}\text { Administration (5), } \\
\text { France (5), HP (5), } \\
\text { Market (5), Microsoft } \\
\text { (5), Web (5) }\end{array}$ \\
\hline Key word 8 & Training (7) & $\begin{array}{l}\text { Computer scientists } \\
\text { (23) }\end{array}$ & $\begin{array}{l}\text { Data (7), Jobs (7), } \\
\text { Start-up (7) }\end{array}$ & $\begin{array}{l}\text { Administration (8), } \\
\text { Training (8), IBM } \\
\text { (8), Project (8), } \\
\text { Tech (8), } \\
\text { Telecoms (8) }\end{array}$ & $\begin{array}{l}\text { Challenges (4), } \\
\text { efficiency (4), } \\
\text { outsourcing (4), } \\
\text { computer scientists } \\
\text { (4), Digital (4), Society } \\
\text { (4), Software and IT } \\
\text { Services Firms (4) }\end{array}$ \\
\hline Key word 9 & & $\begin{array}{lr}\text { France } & (22), \\
\text { Software } & \text { and IT } \\
\text { Services } & \text { Firms } \\
(22), \text { Start-up (22) }\end{array}$ & $\begin{array}{l}\text { Electronic (6), } \\
\text { Software (6), } \\
\text { Wages (6), Work(6) }\end{array}$ & $\begin{array}{l}\text { Clients (7), } \\
\text { Compaq (7), Data } \\
\text { (7), Employment } \\
\text { (7), high (7), } \\
\text { Computer } \\
\text { sciences (7), } \\
\text { Integration (7), } \\
\text { J2EE (7), market } \\
\text { (7), computer (7), } \\
\text { tool (7), price (7), } \\
\text { system (7) }\end{array}$ & Years (3) Client (3) \\
\hline Key word 10 & & Sites (21) & $\begin{array}{l}\text { Applications (5), } \\
\text { Skills (5), Contact } \\
\text { (5), New Economy } \\
\text { (5), Editors (5), } \\
\text { Europe (5), Intranet }\end{array}$ & $\begin{array}{l}\text { Bench (6), Bull (6), } \\
\text { CIO (6), French } \\
\text { (6), Information } \\
\text { (6), Intel (6), Line } \\
\text { (6), Management }\end{array}$ & \\
\hline
\end{tabular}




\begin{tabular}{|l|l|l|l|l|}
\hline & & & (5), Telecoms (5) & $\begin{array}{l}\text { (6), Microsoft (6), } \\
\text { software (6), SAP } \\
(6)\end{array}$ \\
\hline
\end{tabular}

- Occurrence of specific themes in special issues of 01 Informatique, 1999-2003 (thematic analysis)

\begin{tabular}{|l|l|l|l|l|l|}
\hline & \multicolumn{1}{|c|}{$\mathbf{1 9 9 9}$} & \multicolumn{1}{|c|}{$\mathbf{2 0 0 0}$} & \multicolumn{1}{c|}{$\mathbf{2 0 0 1}$} & \multicolumn{1}{c|}{$\mathbf{2 0 0 3}$} \\
\hline RT & $0 \%$ & $0 \%$ & $0 \%$ & $0 \%$ & $0 \%$ \\
\hline IT & $5 \%(2)$ & $0 \%$ & $0 \%$ & $2.4 \%(1)$ & $2.5 \%(1)$ \\
\hline PGES & $17.5 \%$ & $20.5 \%(9)$ & $7.5 \%(3)$ & $14.6 \%(6)$ & $21 \%(4)$ \\
\hline COMP & $2.5 \%(1)$ & $4.5 \%(2)$ & $5 \%(2)$ & $4.9 \%(2)$ & $2.5 \%(1)$ \\
\hline EVO & $5 \%(2)$ & $11.4 \%(5)$ & $15 \%(6)$ & $14.6 \%(6)$ & $15.8 \%(3)$ \\
\hline CONJ & $12.5 \%(5)$ & $9.1 \%(4)$ & $2.5 \%(1)$ & $4.9 \%(2)$ & $0 \%$ \\
\hline STAN & $2.5 \%(1)$ & $0 \%$ & $0 \%$ & $0 \%$ & $0 \%$ \\
\hline CPT & $2.5 \%(1)$ & $0 \%$ & $0 \%$ & $0 \%$ & $0 \%$ \\
\hline EVA & $2.5 \%(1)$ & $9.1 \%(4)$ & $27.5 \%(11)$ & $17.1 \%(7)$ & $10.5 \%(2)$ \\
\hline CHX & $0 \%$ & $0 \%$ & $0 \%$ & $4.9 \%(2)$ & $10.5 \%(2)$ \\
\hline MUT & $0 \%$ & $4.5 \%(2)$ & $2.5 \%(1)$ & $2.4 \%(1)$ & $0 \%$ \\
\hline EMP & $27.5 \%(11)$ & $20.15 \%(9)$ & $22.5 \%(9)$ & $19.5 \%(8)$ & $21 \%(4)$ \\
\hline APPLI & $5 \%(2)$ & $6.8 \%(3)$ & $7.5 \%(3)$ & $4.9 \%(2)$ & $0 \%$ \\
\hline ACCT & $5 \%(2)$ & $6.8 \%(3)$ & $7.5 \%(3)$ & $9.8 \%(4)$ & $0 \%$ \\
\hline INNO & $12.5 \%$ & $0 \%$ & $2.5 \%$ & $0 \%$ & $2.5 \%(1)$ \\
\hline
\end{tabular}

- Occurrence of specific themes for special issues of Infoweek during 1999-2003 (thematic analysis)

\begin{tabular}{|c|c|c|c|c|c|}
\hline & 1999 & 2000 & 2001 & 2002 & 2003 \\
\hline POL-CA & $21.2 \%$ & $27.2 \%$ & $22.9 \%$ & $26.1 \%$ & $25.1 \%$ \\
\hline RT & $0.0 \%$ & $0.2 \%$ & $0.7 \%$ & $0.2 \%$ & $0.4 \%$ \\
\hline IT & $0.1 \%$ & $0.3 \%$ & $1.1 \%$ & $1.2 \%$ & $1.0 \%$ \\
\hline CROY-SI & $0.2 \%$ & $0.3 \%$ & $0.4 \%$ & $0.6 \%$ & $0.6 \%$ \\
\hline COMP & $0.6 \%$ & $0.8 \%$ & $0.1 \%$ & $0.2 \%$ & $0.4 \%$ \\
\hline EVO & $4.3 \%$ & $9.0 \%$ & $3.6 \%$ & $4.3 \%$ & $5.1 \%$ \\
\hline STAN & $1.6 \%$ & $0.5 \%$ & $0.4 \%$ & $0.5 \%$ & $0.6 \%$ \\
\hline ESE & $3.1 \%$ & $9.0 \%$ & $11.5 \%$ & $9.6 \%$ & $13.4 \%$ \\
\hline EVA-C & $9.4 \%$ & $9.6 \%$ & $15.4 \%$ & $13.4 \%$ & $12.6 \%$ \\
\hline EVA-P & $33.3 \%$ & $25.2 \%$ & $2.3 \%$ & $2.1 \%$ & $0.8 \%$ \\
\hline CHX & $5.6 \%$ & $5.0 \%$ & $4.1 \%$ & $0.9 \%$ & $0.4 \%$ \\
\hline MUTA-C & $2.5 \%$ & $1.8 \%$ & $8.5 \%$ & $8.4 \%$ & $5.1 \%$ \\
\hline MUTA-P & $5.6 \%$ & $1.3 \%$ & $3.8 \%$ & $2.4 \%$ & $2.2 \%$ \\
\hline EMP & $4.0 \%$ & $5.5 \%$ & $5.9 \%$ & $6.7 \%$ & $5.9 \%$ \\
\hline APPLI-UT & $0.8 \%$ & $0.5 \%$ & $2.5 \%$ & $2.7 \%$ & $1.8 \%$ \\
\hline APPLI-ORG & $2.8 \%$ & $1.0 \%$ & $7.2 \%$ & $11.4 \%$ & $17.2 \%$ \\
\hline APPLI-SOC & $0.2 \%$ & $1.1 \%$ & $2.9 \%$ & $4.4 \%$ & $3.8 \%$ \\
\hline ACCT & $0.8 \%$ & $0.5 \%$ & $0.8 \%$ & $0.5 \%$ & $0.4 \%$ \\
\hline INNO & $3.7 \%$ & $1.5 \%$ & $6.0 \%$ & $4.6 \%$ & $3.2 \%$ \\
\hline TOTAL & $100.0 \%$ & $100.0 \%$ & $100.0 \%$ & $100.0 \%$ & $100.0^{\circ}$ \\
\hline
\end{tabular}

\section{A.2 Overview of longitudinal case-studies: presentation of each case's main features}




\section{A.2.1 Overview of American longitudinal case-studies}

\begin{tabular}{|c|c|c|c|}
\hline & Case & IS main features & $\begin{array}{l}\text { Main socio-technical dynamic for the } 1999- \\
2003 \text { period }\end{array}$ \\
\hline 1 & $\begin{array}{l}\text { LDS hospital (Salt } \\
\text { Lake City) } \\
\text { [Doolan and al. 2003]; } \\
\text { [Gardner and al. 1999] }\end{array}$ & $\begin{array}{l}\text { "HELP system": integrated, packaged IS, } \\
\text { mainly internally developed since } 1963 . \\
\text { Operational since } 1963 \text {. Required years of } \\
\text { programming. Today, the system has been } \\
\text { implemented in a dozen hospitals. } \\
\text { The system offers numerous decision- } \\
\text { support facilities in various areas of health } \\
\text { organizations management. }\end{array}$ & $\begin{array}{l}\text { Each patient's room is equipped with a } \\
\text { computer, in order to feed in real time data, } \\
\text { and in order to access information at any time } \\
\text { (ERP). } \\
\text { Today, doctors are primarily data readers and } \\
\text { not data collectors (as in most health } \\
\text { organisations). } \\
\text { Indeed, this is the only observation that does } \\
\text { not stick to the broader OV dynamic. } \\
\text { In 1998, two broad evolutions can be noted: } \\
\text { i) Longitudinal storage of data on patients with } \\
\text { a data warehouse } \\
\text { Objective: to trace the healthcare itinerary of } \\
\text { each patient, and locate them within broader } \\
\text { processes (ERP) } \\
\text { ii) Use of technologies/more recent user } \\
\text { interface }\end{array}$ \\
\hline 2 & $\begin{array}{l}\text { Wishard Memorial } \\
\text { Hospital, Indianapolis } \\
\\
\text { [Doolan and al. 2003]; } \\
\text { [American Hospital } \\
\text { Association 2000] }\end{array}$ & $\begin{array}{l}\text { IS developed by an external organization } \\
\text { since } 1972 \text {. } \\
\text { Development carried out over several } \\
\text { decades. } \\
\text { "The system was designed to add value to } \\
\text { physicians' work, fit the local care process, } \\
\text { be clinically "smart," fast, flexible, and user- } \\
\text { friendly. To be clinically "smart" the } \\
\text { physician order entry was built on an } \\
\text { electronic medical record system that would } \\
\text { allow the physician to easily retrieve and } \\
\text { organize patient information. " }\end{array}$ & $\begin{array}{l}\text { Main objective: to help doctors in their } \\
\text { everyday activity (to give added value to their } \\
\text { work } \\
\text { Implementation strategy): } \\
\text { - To give doctors access to information before } \\
\text { asking them to collect data themselves; } \\
\text { - Asking for continuous recording from users } \\
\text { ("process traceability"). } \\
\text { Results: high amount of data collected directly } \\
\text { by doctors. Decision support system widely } \\
\text { used by doctors. }\end{array}$ \\
\hline 3 & $\begin{array}{l}\text { Brigham and Women's } \\
\text { Hospital (Boston) } \\
\text { [Doolan and al. 2003]; } \\
\text { [American Hospital } \\
\text { Association, 2000]; } \\
\text { [Teich et al. 1999] }\end{array}$ & $\begin{array}{l}\text { Brigham Integrated Computing System } \\
\text { (BICS): solution internally developed since } \\
\text { 1984. } \\
\text { The decision support facilities are extremely } \\
\text { important: } \\
\text { "The order-entry system was developed in } \\
1992 \text { and has played a large role in } \\
\text { improving care and reducing cost through } \\
\text { the use of electronic communication, alerts, } \\
\text { reminders, and algorithms to promote } \\
\text { appropriate care, prevent adverse events, } \\
\text { and improve the utilization of resources." } \\
\end{array}$ & $\begin{array}{l}\text { IS functionalities have been gradually } \\
\text { implemented, enabling users to cope with the } \\
\text { technical change. } \\
\text { IS designers did their utmost to homogenise } \\
\text { users' interface with various software. }\end{array}$ \\
\hline 4 & $\begin{array}{l}\text { Queen's Medical } \\
\text { Center (Honolulu) } \\
\text { [Doolan et al. 2003]; } \\
\text { [Wong 2001] } \\
\end{array}$ & $\begin{array}{l}\text { IS made up of several commercial tools, } \\
\text { implemented since } 1995\end{array}$ & Only between two and three years t \\
\hline 5 & $\begin{array}{l}\text { Veteran's Affairs Puget } \\
\text { Sound (Seattle \& } \\
\text { Tacoma) } \\
\text { [Doolan et al. 2003] }\end{array}$ & $\begin{array}{l}\text { VAPS = Third pilot site for the "Veterans' } \\
\text { Affairs Computerized Patient Record } \\
\text { System" (1997). }\end{array}$ & $\begin{array}{l}\text { nign level of computerized prescriptions } \\
\text { carried out by doctors themselves. }\end{array}$ \\
\hline 6 & $\begin{array}{l}\text { Kaiser Permanente } \\
\text { Northwest (Portland) } \\
\text { [Chin \& Krall 1998] }\end{array}$ & $\begin{array}{l}\text { IS made up of two sub-systems: a results } \\
\text { reporting system (developed in the early } \\
90 \text { 's) and a clinical IS, highly integrated and } \\
\text { implemented since } 1994 \\
\text { "We are a vertically integrated health care } \\
\text { delivery system, providing the majority of } \\
\text { care services under one umbrella". }\end{array}$ & $\begin{array}{l}\text { Main objective of the strategy implemented: to } \\
\text { convince doctors of IS's potential added-value } \\
\text { They try to appeal to doctors through e-mails } \\
\text { and patient-recording. They are thus shown } \\
\text { how IT can contribute to improving patient } \\
\text { management. } \\
\text { A clinical IS with intuitive user's interface, } \\
\text { enabling a recurrent adaptation of the system }\end{array}$ \\
\hline
\end{tabular}




\begin{tabular}{|c|c|c|c|}
\hline & & & $\begin{array}{l}\text { is chosen, with little need for training. } \\
\text { They adapt the system as much as possible } \\
\text { to the doctor's needs during the pilot phase, } \\
\text { depending on their requirements. } \\
\text { Result: an increase in doctors' satisfaction } \\
(86 \%)+\text { information related to prescriptions } \\
\text { directly collected by doctors }\end{array}$ \\
\hline 7 & [Marchioni 2001] & $\begin{array}{l}\text { Longitudinal case study on the } 1996-2001 \\
\text { period. Based on the co-construction of } \\
\text { Internet technologies and its users in the } \\
\text { U.S. Bureau of Labour Statistics (BLS) }\end{array}$ & $\begin{array}{l}\text { "BLS as an institution and its organizational } \\
\text { interface has likely changed more than is } \\
\text { apparent due to the adoption of the Internet } \\
\text { and WWW-based user interfaces. The } \\
\text { physical changes are highlighted in the other } \\
\text { dimensions as new hardware, personnel, and } \\
\text { budgets become institutionalized. The } \\
\text { corporate culture changes are subtler and are } \\
\text { reflected somewhat in the commentary of BLS } \\
\text { staff about changed work behaviour, personal } \\
\text { accountability, and morale. More basic } \\
\text { changes in corporate policies and mission will } \\
\text { take longer and some early indicators are } \\
\text { evident in the security awareness and quality- } \\
\text { control levels. A significant change is that the } \\
\text { website and its user interface has become } \\
\text { part of the fundamental organizational } \\
\text { interface of BLS and these interfaces will } \\
\text { continue to interact with changes in } \\
\text { technology, data, and people to influence BLS } \\
\text { in the years ahead (p 25)." }\end{array}$ \\
\hline 8 & $\begin{array}{l}\text { [Majchrzack, Rice, } \\
\text { Malhotra and King } \\
\text { 2000] }\end{array}$ & $\begin{array}{l}\text { Longitudinal case studies about the } \\
\text { enactment or an inter-organisational virtual. } \\
\text { Ten months' observation in } 1999 \text { ("This } \\
\text { study analyzes how an inter-organizational } \\
\text { virtual team, tasked with creating a highly } \\
\text { innovative product over a } 10 \text { month period, } \\
\text { adapted the use of a collaborative } \\
\text { technology and successfully achieved its } \\
\text { challenging objectives. The study of such a } \\
\text { virtual team is especially useful for } \\
\text { extending our understanding of the } \\
\text { adaptation process as virtual teams have } \\
\text { more malleable structures than typical } \\
\text { organizational units and controlled group } \\
\text { experiments.") }\end{array}$ & $\begin{array}{l}\text { Describe an adaptation process of a } \\
\text { technology in an unusual environment, a } \\
\text { virtual work group ("We found that the team } \\
\text { initially experienced significant misalignments } \\
\text { among the pre-existing organizational } \\
\text { environment, group, and technology } \\
\text { structures. To resolve these misalignments, } \\
\text { the team modified the organizational } \\
\text { environment and group structures, leaving the } \\
\text { technology structure intact. However, as the } \\
\text { team proceeded, a series of events unfolded } \\
\text { that caused the team to reevaluate and } \\
\text { further modify its structures. This final set of } \\
\text { modifications involved reverting back to the } \\
\text { pre-existing organizational environment, while } \\
\text { new technology and group structures } \\
\text { emerged as different from both the pre- } \\
\text { existing and the initial ones. A new model of } \\
\text { the adaptation process-one that integrates } \\
\text { these findings and those of several previous } \\
\text { models-is proposed.") }\end{array}$ \\
\hline 9 & [Ash, Burn 2003] & $\begin{array}{l}\text { - 1999-2000 } \\
\text { First round of interviews in November 1999; } \\
\text { two rounds of interviews in June-July 2000, } \\
\text { with a structured interview guides, } \\
\text { supplemented by reading internal archives } \\
\text { Target: senior project managers and team } \\
\text { members } \\
\text { - Project for an integrated architecture of an } \\
\text { e-learning system between Dell and one of } \\
\text { its big customers (between a customer's } \\
\text { ERP and Dell's supply chain. The objective } \\
\text { was to identify success indicators for } \\
\text { implementing a project linking an ERP and }\end{array}$ & $\begin{array}{l}\text { Project of an integrated architecture of an e- } \\
\text { learning system between Dell and one of its } \\
\text { big customer (between a customer's ERP and } \\
\text { the supply chain of Dell). The objective was to } \\
\text { identify success indicators of the } \\
\text { implementation of a project of connection } \\
\text { between an ERP and an e-business system. }\end{array}$ \\
\hline
\end{tabular}




\begin{tabular}{|l|l|l|l|}
\hline & & an e-business system. & \\
\hline $\mathbf{1 0}$ & [Hughes, Stone 2002] & $\begin{array}{l}\text { Pilot case-study carried out in December } \\
1999 \text { and January 2000 } \\
\text { Other interviews have been conducted } \\
\text { between July and December 2000 } \\
\text { In-depth semi-directed interviews with 30 } \\
\text { senior managers of various departments }\end{array}$ & $\begin{array}{l}\text { The study was carried out in two different } \\
\text { firms. The project was similar in both firms, } \\
\text { same activity (banking): implementation of a } \\
\text { website for its major customers (professional) } \\
\text { in order to carry out on-line transactions. }\end{array}$ \\
\hline $\mathbf{1 1}$ & $\begin{array}{l}\text { [Mieczkowska, Barnes, } \\
\text { Hinton 2002] }\end{array}$ & $\begin{array}{l}1999 \\
\text { Semi-directed interviews, recorded with key } \\
\text { agents involved in e-commerce } \\
\text { implementation. }\end{array}$ & $\begin{array}{l}\text { Objective of the research: impact of e- } \\
\text { commerce adoption of firm's key processes. } \\
\text { Project for customer information feedback to } \\
\text { the various departments. }\end{array}$ \\
\hline $\mathbf{1 2}$ & $\begin{array}{l}\text { 2000 } \\
\text { Participating research: a team of } \\
\text { researchers served as consultants for the } \\
\text { project. }\end{array}$ & $\begin{array}{l}\text { Bloomsburg Carpet. Implementation of an } \\
\text { electronic catalogue for customers, enabling } \\
\text { multi-criteria research. }\end{array}$ \\
\hline
\end{tabular}

\section{A.2.2 Overview of French case-studies}

\begin{tabular}{|c|c|c|c|}
\hline $\mathbf{N}^{\circ}$ & Case & IS main features & $\begin{array}{c}\text { Main socio-technical dynamic for the 1999-2003 } \\
\text { period }\end{array}$ \\
\hline $\mathbf{a}$ & [Romeyer 2001] & $\begin{array}{l}\text { Longitudinal case study on } \\
\text { implementation of patient- } \\
\text { processing IS, (administrative, } \\
\text { medical, paramedical, etc.), } \\
\text { over the 1997-2000 period }\end{array}$ & $\begin{array}{l}\text { At the beginning of the project, several software } \\
\text { applications with various kinds of interfaces could be } \\
\text { implemented. } \\
\text { Project manager hoped thus to lead the organization to } \\
\text { be the first hospital to implement an effective } \\
\text { communication technology centred on patient } \\
\text { processing. } \\
\text { Since } 2000 \text {, the project has been deeply transformed: } \\
\text { in view of the numerous interface problems between } \\
\text { the various technologies in use, the hospital decided to } \\
\text { focus most of the IS on the integrated modules of a } \\
\text { single editor. } \\
\text { The discourse, which had been until this point rather } \\
\text { positive, began to turn towards the negative. } \\
\text { The reinforcement of IS implementation seemed } \\
\text { necessary. }\end{array}$ \\
\hline b & $\begin{array}{l}\text { [de Vaujany 2001, } \\
\text { 2003] }\end{array}$ & $\begin{array}{l}\text { For case studies about intranet } \\
\text { implementation in big French firms, } \\
\text { mainly during the 1999-2001 } \\
\text { period. }\end{array}$ & $\begin{array}{l}\text { Internal boundaries of the organization are largely } \\
\text { reproduced and reinforced by tools, even if they are } \\
\text { presented as de-compartmentalizing objects. } \\
\text { Sometimes an intranet contributes to organizational } \\
\text { knowledge- and skills-crossings, but only as a catalyst } \\
\text { since agents or departments already involved in cross- } \\
\text { organizational dynamics unrelated to technological } \\
\text { fields. }\end{array}$ \\
\hline C & $\begin{array}{l}\text { [Chetioui Ben Osman } \\
\text { L. 2004] }\end{array}$ & $\begin{array}{l}\text { - 1999-2001 } \\
\text { - Project: to put on line customer } \\
\text { services: "internet spaces for retail } \\
\text { customers. The project } \\
\text { experienced stop and go periods } \\
\text { during two years. } \\
\text { - French firm involved in banking } \\
\text { activities } \\
\text { - Method: interviews, review of e- } \\
\text { mails and internal documentation. } \\
\end{array}$ & $\begin{array}{l}\text { A project which: } \\
\text { - Was heavily influenced by external discourses (by } \\
\text { competitors, consultants, books). The point is to "to } \\
\text { conform to existing practices', } \\
\text { - Did not start from scratch as the bank had already } \\
\text { some experience in telecommunication, } \\
\text { - Was constrained by internal conflicts. The project } \\
\text { really started during the rise of "e-business" and "e- } \\
\text { commerce" OV (2000 and 2001). }\end{array}$ \\
\hline d & $\begin{array}{l}\text { [Bourgeois Carton } \\
\text { 1999] }\end{array}$ & $\begin{array}{l}\text { - } 1994 \text { - } 2003 \\
\text { - Project: implementation of an } \\
\text { electronic product catalogue - } \\
\text { Large French group involved in } \\
\text { energy activities }\end{array}$ & $\begin{array}{l}\text { A project which: } \\
\text { - was strongly influenced by external discourses } \\
\text { (competitors) insisting on potential savings, } \\
\text { - was promoted internally by relying in externally } \\
\text { discourses (consultants, books, American press...: }\end{array}$ \\
\hline
\end{tabular}




\begin{tabular}{|c|c|c|c|}
\hline & & $\begin{array}{l}\text { - Method: participating research } \\
\text { during three years (meetings, } \\
\text { project), interviews, review of } \\
\text { internal documents }\end{array}$ & $\begin{array}{l}\text { "the emergence of electronic business is today an } \\
\text { unavoidable reality". } \\
\text { - Began during the beginning of the "electronic } \\
\text { commerce" and "e business" OV (1999). }\end{array}$ \\
\hline e & [Deltour 2003] & $\begin{array}{l}\text { Study on levers of Intranet } \\
\text { consultation) } \\
\text { The intranet was launched in } 1998 \\
\text { within a banking structure } \\
\text { Suggest to study individual, } \\
\text { organizational and technical levers } \\
\text { that may favour the use of intranet } \\
\text { at an individual level }\end{array}$ & $\begin{array}{l}\text { An empirical evaluation is achieved by } 149 \text { employees } \\
\text { working within the commercial network of a French } \\
\text { bank, and having a documentary intranet at their } \\
\text { disposal. } \\
\text { Results suggest few levers clearly favouring the } \\
\text { consultation of the Intranet. } \\
\text { In particular, it seems that potential levers will differ in } \\
\text { accordance with the parts of the Intranet. } \\
\text { Still limited, Intranet consultation boils down to } \\
\text { individual factors that are difficult to influence. }\end{array}$ \\
\hline $\mathbf{f}$ & $\begin{array}{l}\text { [Vaast and Benghozi } \\
\text { 2000] }\end{array}$ & $\begin{array}{l}\text { Set of cases (12) on Intranet } \\
\text { implementation for } 1999-2000\end{array}$ & $\begin{array}{l}\text { In accordance with our analysis, implementation and } \\
\text { evolution of an intranet corresponded to a succession } \\
\text { of some shared and specific tendencies; to gradual } \\
\text { evolutions and to more radical evolutions, to local and } \\
\text { global learning. } \\
\text { This diversity means that intranets are not simply } \\
\text { technologies } \\
\text { The minimal technical definitions often put forward, } \\
\text { based on Internet standards, and based on the internal } \\
\text { network of the firm, are thus unsatisfying } \\
\text { Indeed, the study of Intranets involves the analysis of } \\
\text { numerous structuring processes, based more on } \\
\text { technology representation than on the technology } \\
\text { itself. } \\
\text { From this perspective, this demonstrates that } \\
\text { opportunities Intranet-related organizing can be } \\
\text { understood and the new coherence of the organization } \\
\text { can be taken into account through three major } \\
\text { movements: local-central, action-communication and } \\
\text { intentional-emergent. }\end{array}$ \\
\hline
\end{tabular}




\section{ABOUT THE AUTHORS}

Sabine Carton is a lecturer of Information Systems at Grenoble University (IAE business School). Her research interests include the international dimension of Information Systems, Technology adoption and appropriation within IS projects. She currently teaches IS project management, database design, and management of global information systems courses.

Research center CERAG UMR 5820

Correspondence:

S.Carton - IAE Grenoble

Université Pierre Mendès France

BP 47

38040 Grenoble cedex 9 - FRANCE

François-Xavier de Vaujany is a lecturer in IS at the Economics and Management Departement (ISEAG) of Jean Monnet University (France) and a member of Preactis research center. His research deals with ICT-related practices examined through sociological (such as structuration or critical realism) and historiographical frameworks. $\mathrm{He}$ is also interested in the instrumentation of IS 'value in use'.

Research center: Préactis

Correspondence:

6 , rue Basse-des-rives

42023 Saint-Etienne - FRANCE

Cécile Romeyer is a lecturer in Information Systems and logistics at the Economics and Management Departement (ISEAG) of Jean Monnet University (France) and a member of Preactis research center. Her research concerns contribution of process models to IS planning, appropriation process within IS projects.

Research center: Préactis 
Correspondence:

6 , rue Basse-des-rives

42023 Saint-Etienne - FRANCE 